RHO-CD-648, REV 1

\title{
REDUCTION OF RADIATION AREA PROJECT PLAN
}

Rockwell Hanford Operations Staff

August 1979

Prepared for the United States

Department of Energy

Under Contract EY-77-C-06-1030

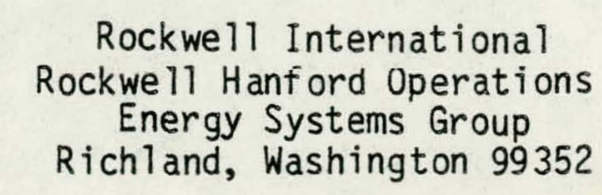

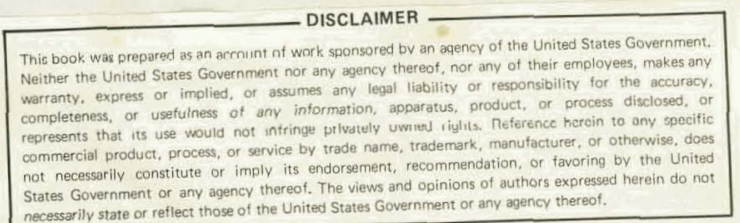




\section{DISCLAIMER}

This report was prepared as an account of work sponsored by an agency of the United States Government. Neither the United States Government nor any agency Thereof, nor any of their employees, makes any warranty, express or implied, or assumes any legal liability or responsibility for the accuracy, completeness, or usefulness of any information, apparatus, product, or process disclosed, or represents that its use would not infringe privately owned rights. Reference herein to any specific commercial product, process, or service by trade name, trademark, manufacturer, or otherwise does not necessarily constitute or imply its endorsement, recommendation, or favoring by the United States Government or any agency thereof. The views and opinions of authors expressed herein do not necessarily state or reflect those of the United States Government or any agency thereof. 


\section{DISCLAIMER}

Portions of this document may be illegible in electronic image products. Images are produced from the best available original document. 
RHO-CD-648, REV 1

\section{CONTENTS}

1. Introduction. .................... 1

Background ..................... 1 Need ....................... 1

2. Surmary ....................... . . 3

3. Scope ......................... 5

General. . . . . . . . . . . . . . . . 5

Past Radiation Area Reduction Activities.......... 5

Current Conditions................ 13

Transport Mechanisms ................. 15

4. Technical Approach. . . . . . . . . . . . . . . 19

Criteria and Standards............... 20

Prioritization of Radiation Area Reduction Activities. . . . 21

Gener ic Approach ....... . . . . . . . . . . 23

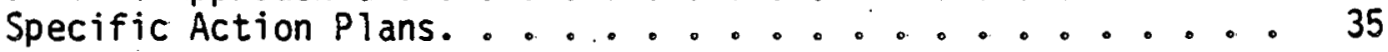

5. Schedules .......................... 41

6. Resource Planning ..................... 47

Heavy Equipment Utilization. . . . . . . . . . . . 47

Expense Funding Plan ............... 47

Capital Funding Pian ................ 49

7. Management and Control............... 51

Program Management and Control ............. 51

Executive Management Review. .............. 53

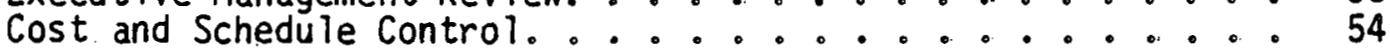

Safety..................... 55

Quality Assurance. .............. 55

Supporting Documentation and Document Control....... 56

Figures:

1. 216-8-43 Through -50 Crib Area Prior to Cleanup and

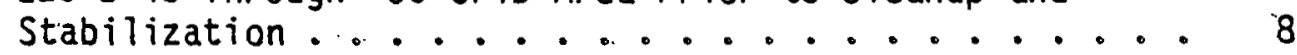

2. 216-8-43 Through -50 Crib Area After Cleanup and

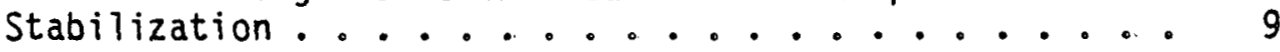




\section{RHO-CD-648; REV 1}

3. Suzie Railroad Siding Subsequent to Cleanup ....... 10

4. Contaminated Dirt Removal at 23rd and Camden. ...... 11

5. 23rd and Camden Following Completion of Cleanup and

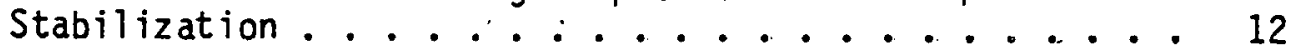

Tables:

1. Expense Funding Plan. . . . . . . . . . . 48 48

2. Capital Budget Plan, Equipment Not Related to

Construction. ............... 50

Appendix

Contaminated Facilities List ............. 59 


\section{INTRODUCTION}

\section{BACKGROUND}

Rockwell Hanford Operations (Rockwell) is responsible for identifying and controlling radiation areas resulting from past and current operations within the 200 Areas and certain designated sites in the 600 Area on the Hanford Site. This control is exercised to prevent the spread of radioactive contamination, minimize the exposure of employees to as low as technically and economically practical (ALATEP), and prevent radiation exposure to the general population.

This plan describes the programmatic approach being taken by Rockwell to reduce outdoor radiation areas. The plan supersedes the Radiation Area Reduction Activity Plan issued January 31, 1979. This is an integrated $p l a n$ for radiation area reduction, and as such, includes several program areas. The 482 facilities included in this radiation area reduction project are listed in the Appendix.

NEED

Efforts have always been undertaken within and adjacent to the 200 . Areas to control and minimize contamination in outdoor radiation areas. As current waste management programs achieve or approach completion of major milestones (e.g., single-shell tank deactivation, liquid evaporation; etc.), increased emphasis is being placed on reduction or elimination of outdoor radiation areas. This increased emphas is has taken the form of cleanup of old radioactive spills, stabilization of old waste disposal sites, and increased radiological surveys. All radiation area reduction efforts identified as part of this plan are being categorized and characterized 'so that those areas presenting the greatest potential. risk are handled first. Any contamination area deemed an immediate safety or environmental concern is handled immediately. Also, a "clean operation" philosophy is being put into place throughout the area. Containment enclosures are used to reduce contamination spread from tank farm operations, as an example. 
The overall radiation area reduction efforts will continue for several years. The near-term efforts during the next 6 months, which are delineated in this document, will concentrate on the following:

1. Immediate cleanup or stabilization of any contamination spreads impacting safety or environment.

2. Surveying and posting of radiation areas.

3. Initiate contamination cleanup and surface stabilization within the burial grounds.

4. Removal of the contaminated dirt berm along the laundry ditch.

5. Development of a cooling water pond management plan.

6. Investigation of possible approaches for reduction or elimination of certain low-level liquid effluents (e.g., laundry).

7. Preparation of plans to identify the specific technical approach for each site to be cleaned or. stabilized.

The Rockwell Radiation Area Reduction Plan integrates under one focal point all program activities related to radiation area reduction and contamination cleanup. Specific actions planned for the next 6 months are discussed in Section 4. 
RHO-CD-648, REV 1

\section{SUMMARY}

This plan deals with the overall reduction of outdoor surface radiation areas under Rockwell's jurisdiction. Four basic alternatives are identified which will reduce and/or stabilize radiation areas until long-term disposal decisions are made. The four alternatives are: (1) continued routine surveillance and maintenance, (2) reduction or elimination of effluent discharges, (3) improved site stabilization, and (4) site removal. The four major transport mechanisms at Hanford that are the primary forces for contamination spread are identified as wind, animal transport, concentration and dispersal by plants, and transport resulting from human activities. These are discussed in terms of overall radiation area reduction.

Past radiation area reduction accomplishments in and adjacent to the 200 Areas are described and the current conditions related to contamination within the 200 Areas are discussed.

The technical approach to the overall project is covered in Section 4 and includes discussions on criteria and standards, prioritization of tasks, the general approach to the problem solution, and a description of the specific action plans. Within the Criteria and Standards section, a discussion of interim surface soil contamination limits is presented. The priorities for field operations will be established based on personnel, occupational, and environmental safety requirements supplemented by recognized practical constraints. The priority list will be periodically reevaluated and updated as new data become available and conditions change.

The generic approach to the project resulted in identification of five operational activities and one technical support activity. The field operations are grouped according to the general solution required to reduce the respective radiation areas. The five groups are reduction of dry surface areas, reduction of wet surface areas, reduction of tank 
RHO-CD-648, REV 1.

farm areas, reduction of BC Cribs and associated areas, and reduction of waste storage areas. There is a sixth activity identified as technical support which includes engineering, planning, and survey efforts.

A schedule is presented covering the specific near-term actions for the next 6 months, and the general efforts through 1984 .

A brief section on resource planning is included, and the section on Management and Control describes the overall management of the project, the Rockwell internal functional responsibilities, and the administrative controls that will be used. 


\section{RHO-CD-648, REV 1}

\section{SCOPE}

\section{GENERAL}

This plan deals with the overall reduction of outdoor surface radiation areas under Rockwell's jurisdiction. Various efforts over the years have been. carried out to control and reduce radiation areas. In an attempt to accelerate and upgrade these efforts, Rockwell has focused the radiation area reduction efforts of several program areas into a single project plan and conducts a continuing overall review of radiological conditions in the 200 Areas. Past occurrence reports were compiled and reviewed: Expanded radiological surveys were initiated. To date, as a result of these activities, approximately 200 acres have been surveyed. Areas requiring corrective action were identified and action initiated. Stabilization and cleanup of some facilities resulted in reducing radiation areas as described below. This project concentrates on elimination of outdoor surface contamination, reduction of contamination sources from effluents, stabilization and isolation of buried radioactive material, and limited removal of radionuclides.

\section{PAST RADIATION AREA REDUCTION ACTIVITIES}

As early as 1954, efforts were underway to reduce surface radiation and contamination by the backfilling of the 216-S-17 Pond. This 17-acre pond currently has 11 acres free of surface contamination, while the other 6 acres have spotty contaminated vegetation. From 1970 through 1975, site records indicate a concerted effort toward reduction of surface radiation areas. Four trenches were exhumed (216-T-9-9, 216-T-9-10, 216-T-9-11, and 216-S-18), as was one crib (216-S-18) and one low-level scrap burial site $(218-E-3)$. Additionally, one trench was released from radiation area status fulluwing radionuclide decay (216-5-14).

The ponds that were decontaminated during the first half of the 1970 's included the 216-S-16 Pond, which had the contaminated surface 
area reduced from 31 to 13 acres; the 216-T-4-1 Pond, which had the contaminated bottom excavated into a trench dug in the pond bottom and covered with clean fill to release 16 acres from surface contamination; and the 216-S-11 Pond, which was covered with clean fill to release the total 1.5 acres of surface area.

Four ditches (216-B-2-1, 216-B-2-2, 216-B-3-1, and 216-B-3-2) were associated with radiation area reduction. in the early 1970's. Each was graded into the center, leveled, had plastic sheeting added for a biobarrier, and had clean fill added. In the areas where the plastic was added, no contaminated vegetation has reappeared.

Two dry waste burial grounds (218-E-1 and 218-W-4-A) were decontaminated on the surface, covered, and released from surface radiation status. The first was covered with. power plant cinders to fill depressions and sterilize the soil, and was then covered with gravel to prevent weather erosion. The second site had a plastic blobarrier installed over the 50- by 50-foot surface area, and then covered with clean soil and revegetated. Neither site has any surface contamination today.

There are also 25 unplanned release sites, both numbered and unnumbered, that were removed from radiation area status during the 1970 to 1975 time period. The sites included liquid and solid spills near roads, vehicle decontamination pits, and a burial ground near White Bluffs. All of these sites provide excellent data on the durability of the various surface stabilization techniques. They will be investigated and the relative conditions factored into current approaches for site stabilization.

During FY 1978, initial progress toward programatically planned reduction of radiation areas was accomplished utilizing funding provided by the Environmental Control Technology (ECT) division of the Department of Energy (DOE). The surface of eight cribs in the 200 East Area associated with B Plant (216-B-43 through -50) was decontaminated and stabilized. As with previous sites, contaminated vegetation and surface soil was removed; a herbicide was spread; a layer of sand, followed by 
RHO-CD-648, REV 1

polyethylene sheet and a second layer of sand, was applied; about 24 inches of clean soil was added over the sand/polyethylene composite; and finally, the surface was revegetated with cheatgrass. This effort resulted in a reduction in the posted radiation area from 3.6 acres to 1.7 acres, and a change in the posted status from SURFACE CONTAMINATION to BUR IED RADIOACTIVE MATERIAL. In addition, no surface dose rate can be measured. See Figures 1 and 2 for "before" and "after" views of this crib area.

Three other areas were also cleaned up in FY 1978. The Suzie railroad siding (Figure 3 ) and the Riverland siding had unplanned releases that were cleaned up. The Suzie siding is located about 2 miles north of the 200 West Area and the Riverland siding is west of the 100 Areas, near the Vernita Bridge. Both sites were used for rail car decontamination. The sites were completely cleaned and the previously posted areas of about one-half acre each were released.

Radiation areas adjacent to the south and east banks of the 207-T Retention Basin were cleaned and released from radiation area status. About one-fourth acre (about half of the original posted area) was removed from posted status.

Progress to date in FY 1979 includes the surface cleanup and stabilization of the 23rd and Camden Street (Figures 4 and 5) unplanned release, UN-216-W-5. The site had about three-fourths acre of posted radiation ared. The site was excavated to about 1-foot depth to remove contaminated soil. Since contamination levels were still in evidence below this depth, herbicide, sand, polyethylene, and sand composite were applied. About 6 inches of gravel was added to stabilize the surface and the site was posted as containing "Buried Radioactive Material". No surface contamination or measurable surface dose rate remained. 


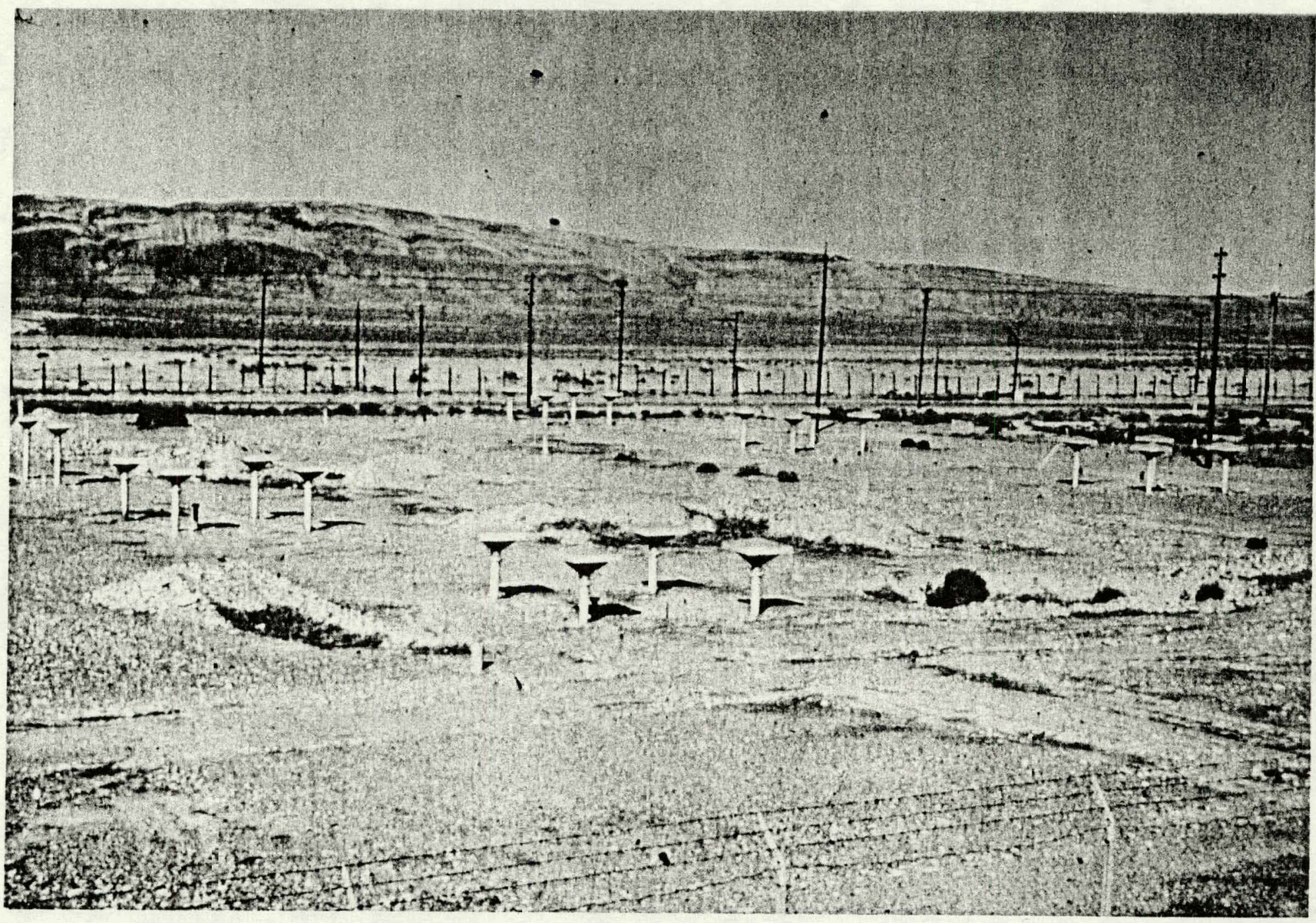

FIGURE 1. 216-B-43 Through 216-B-50 Crit Area Prior to Cleanup and Stabilization. 


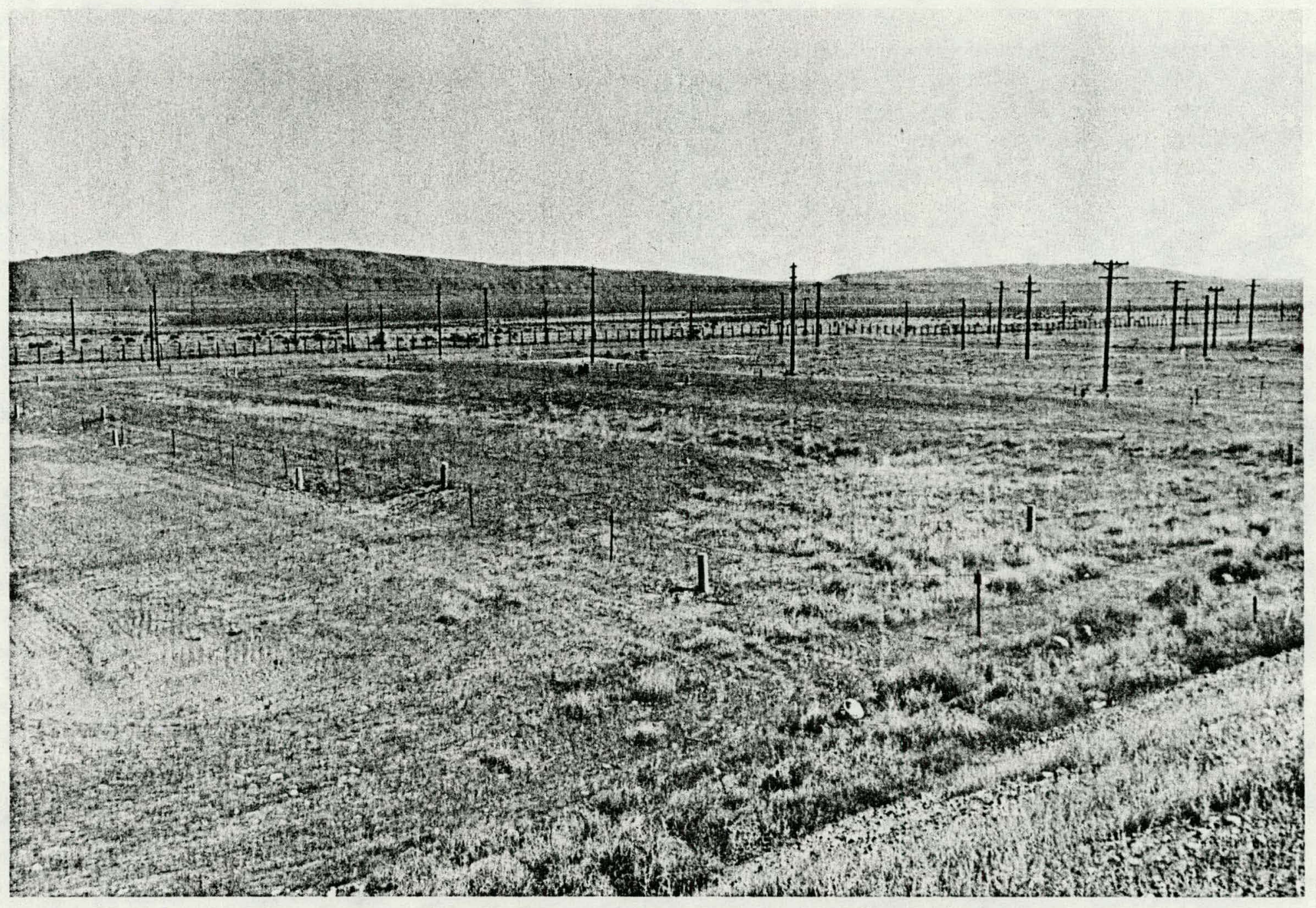

FIGURE 2. 216-B-43 Through 216-B-50 Crib Area After Cleanup and Stabilization. 


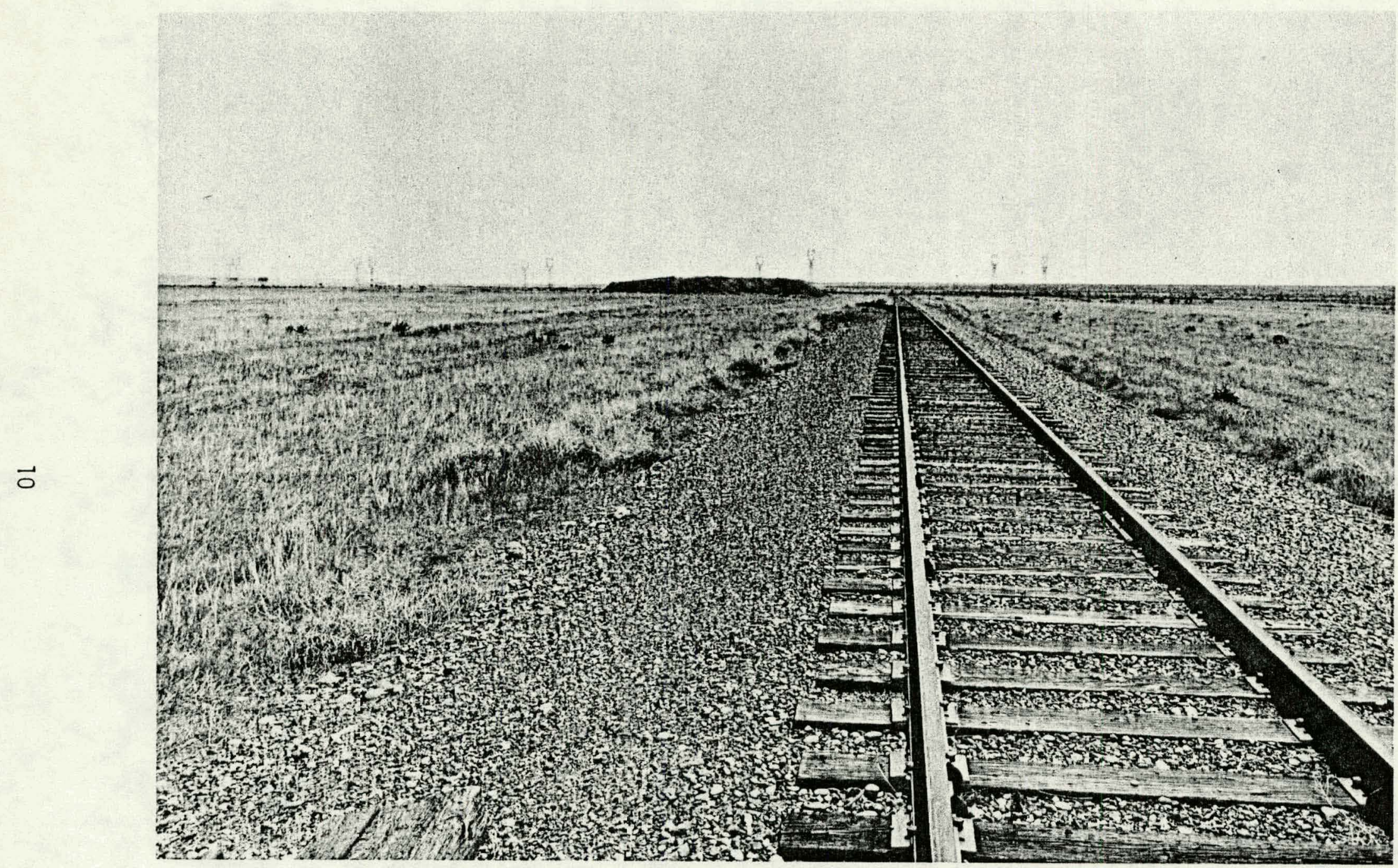

RCP7907-131

FIGURE 3. Suzie Railroad Siding Subsequent to Cleanup. 


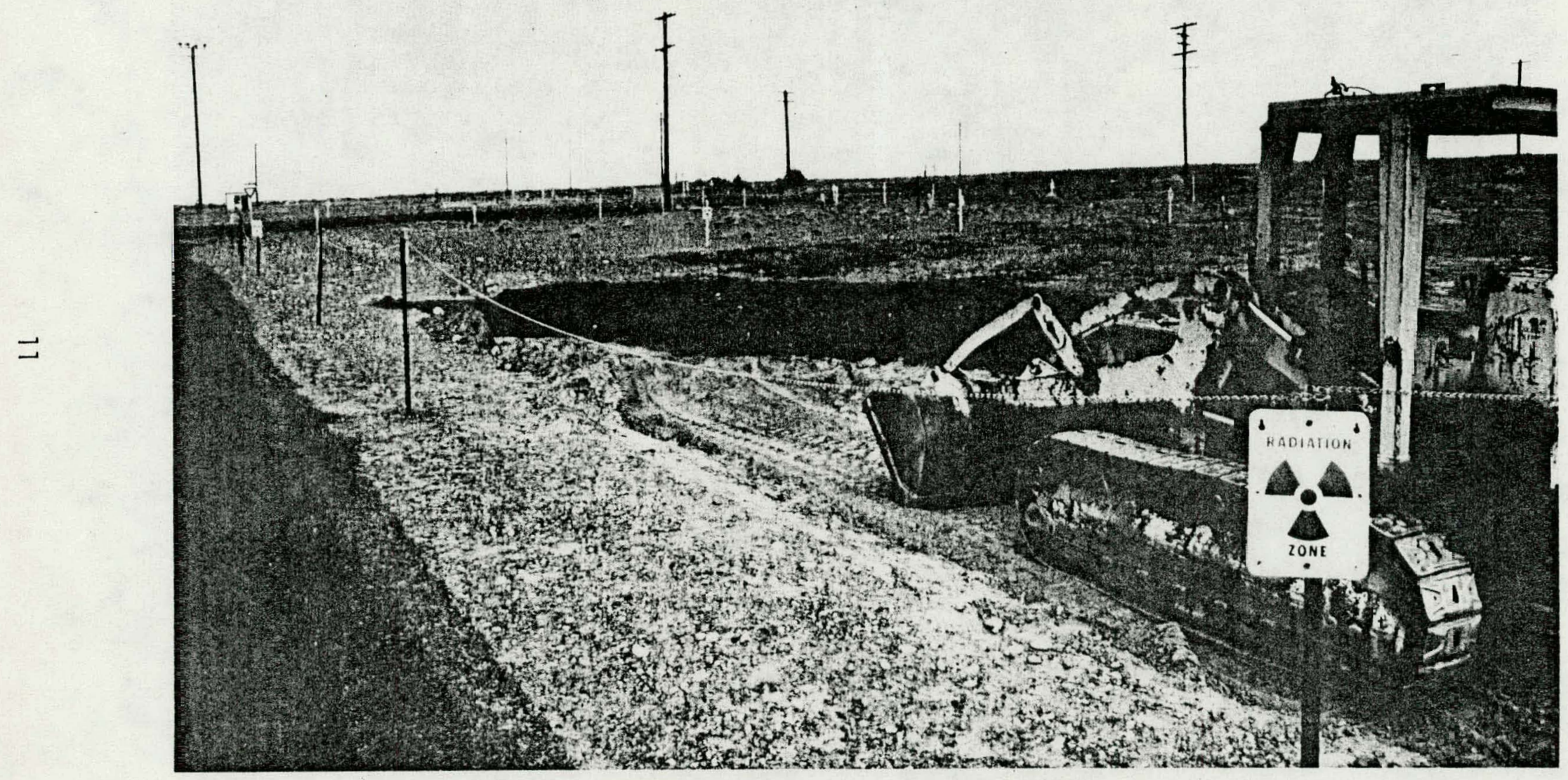

FIGURE 4. Contaminated Dirt Removal at 23rd and Camden. 


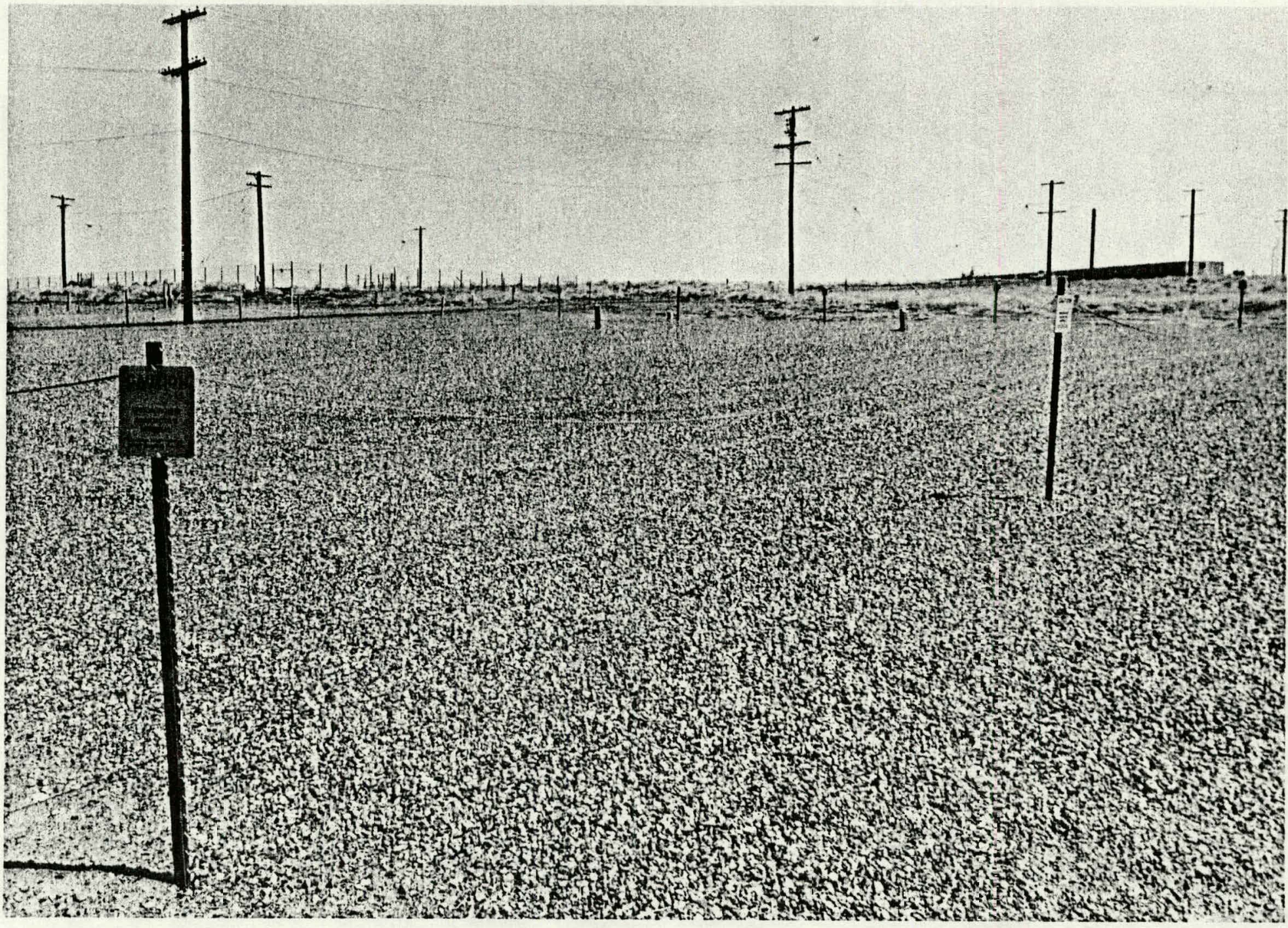

FIGURE 5. 23rd and Camden Following Completion of Cleanup and Stabilization. 
Also underway this year is the cleanup and stabilization of low-level waste burial grounds in the 200 Areas. A complete aerial photographic survey of the 200 Area burial grounds was made. The photos were compared to existing plot $p l a n s$, and sketches were made of the access roads and trenches located in the 218-E-12A and 218-W-2A Burial Grounds. General procedures were prepared to initiate cleanup and stabilization of the burial grounds. Access roads have been identified, staked, stabilized, and ballasted with rock; the trenches have been load tested and depressions filled; grading and sand filling of the trenches has also begun. The next operation in the 218-E-12A Burial Ground will be to cover the trenches with clean sand, polyethylene, and more sand; cover with about 24 inches of clean soil; and revegetate. This burial ground will be completed during calendar year 1979.

Additional work this year includes ditch stabilization. The contaminated U-14 Ditch berm has been removed and buried from the laundry discharge outflow to 19 th Street. Work is continuing from 16 th Street to $\checkmark$ Pond. To date approximately 1000 feet of berm have been removed and buried.

Other efforts continued that indirectly resulted in the reduction or prevention of new radiation areas. An example of a major task that prevented further spread of contamination was the repair of the Redox canyon roof. Twenty thous and square feet of roofing was repaired by the resaturation process. About 600 square feet of the original roof membrane was replaced due to damage. The remaining area was restored by the use of specially formulated solvents. A report was prepared documenting the results of this effort, for use by DOE and other contractors.

\section{CURRENT CONDITIONS}

Established radiation areas associated with past or present operational processes consist of tank farms, diversion boxes, cribs, ponds; ditches, trenches, french drains, reverse wells, burial grounds, retention basins, and pipelines. In addition, some unplanned radiological 
releases occurred during past operations, which are also identified as radiation areas. These unplanned release areas have been identified for control purposes because of the presence of loose surface contamination, the presence of subsurface contamination, which is accessible to vegetation and burrowing animals, or because the inventory of radioactive material present creates an external radiation field. There are also. other locations within the 200 Areas which are contaminated with detectable amounts of radioactivity that are outside the bourdaries of identified operating sites. The general boundaries of these areas have been established from historical data, aerial surveys, and routine environmental surveys. This contamination has resulted from the transport of detectable amounts of radioactivity from established radiation areas and. from unplanned release sites. Controlled movement of personnel and equipment into and out of posted radiation areas prevents spread of radioactive materials by that mechanism. However, detectable amounts of radioactive material are moved from the controlled areas by wind or biological transport modes.

Unplanned releases are treated as they occur by a suitable combination of decontamination, partial decontamination, and covering an area with clean soil. All previous unplanned releases were surveyed and were either concluded to be uncontaminated at that time or identified as a radiation area. The instruments used for surveying in the past were not as sensitive as present instruments; therefore, some residual contamination not previously detectable may be present. Also, the action of wind and biological transport may result in redistribution of radioactivity and the presence of surface contamination may exist in areas which previously were not cleariy identifled. Extenstve surveys have been cunducted of locations accessible to 200 Area personnel not associated. with controlled field work, such as roads, areas surrounding facilities, and parking lots. These surveys have established that these areas are free from contamination and significant radiation fields. 
Environmental monitoring programs are conducted both with in the 200 Areas and beyond the boundaries of the areas. Within the 200 Areas, a gridwork of sites is systematically assayed for external radiation fields, radioactivity concentrations in soil and vegetation, and other evidence of biological transport. These data are used to control radionuclide transport by identifying areas requiring immediate cleanup or stabilization. In addition, a series of air monitoring stations are used to measure the concentration of airborne radioactive material and sample wells are used to monitor radioactivity concentrations in ground water.

Similar monitoring is performed at a network of sites outside the 200 Areas. Data from both the 200 Area and outside area monitoring programs indicate that no health hazard of consequence exists for the 200 Area employees, and that current operations within the 200 Areas have had no measurable effect on environmental conditions outside the Hanford Site.

\section{TRANSPORT MECHANISMS}

As stated previously, the transport of contamination within the 200 Areas has not resulted in any measurable effects to the environment off the Hanford Site. The incentive for radiation area reduction is to eliminate the potential hazard for exposure to 200 Area operating personnel and to reduce even further the already low probability for contamination exposure to the public. In order to control the contamination present in the 200 Areas, the mechanisms for transporting the radionuclides must be identified and understood.

A variety of mechanisms may transport radioactive material from existing radiation sources. This project is directed toward isolating or eliminating the sources of radioactivity which are susceptible to transport and also toward controlling the transport mechan ism where possible until the sources are eliminated. The following are recognized as primary means of movement of radioactivity. 
Wind

Where radioactive material in particulate form is present on or near the soil surface, erosion and subsequent transport by wind may occur. Strong winds may transport contamination beyond the established boundaries of a radiation area. Because of gravitation settling, transport over significant distances does not occur except for very small particles. Dustdevils, however, because of the higher internal velocities and the altitude reached by a rapidly upward-moving thermal, can lift heavier particles higher into the air, with very dilute fallout subsequentiy occurring downwind. No evidence exists as part of the environmental monitoring program which would indicate that significant quantities of radioactive materials are transported offsite by this mechanism.

\section{Animal Transport}

Native animals in the Hanford environment are a possible mechanism for the transport of radionuclides. Rodents, particularly mice; may obtain access to radioactive material in some waste-disposal and wastehandling sites. The mice may become contaminated externally, or even. ingest material like salts. A variety of predators which prey on the rodents, and even the rodents themselves, continue the chain of dispersion by depositing subsequently contaminated urine and feces over a larger area. Birds have access to potentially contaminated mud and vegetation from ponds and ditches for use in building nests, or may even ingest. the vegetation, thus spreading the radioactive material. This transport mechanism has been thoroughly studied by Battelle's Pacific Northwest Laboratory and does not represent a significant $r$ isk to Hanford personnel or the public.

Concentration and Dispersal by Plants

Outdoor waste-disposal sites and sites where underground leaks have occurred support the growth of some vegetation that have roots which can reach the radioactive material. Certain of these plants concentrate the specific nuclides in their cellular structure and are then subject to 


$$
\text { RHO-CD-648, REV } 1
$$

transport by animals or wind. Most notable are tumbleweeds which have deep roots and selectively concentrate strontium and, to a lesser extent, cesium. The tumbleweeds, when dry, break off and are transported by wind. Although studies have shown that the rolling range of the tumbleweeds is short on the Hanford Site, elimination of this transport mechan ism is desirable.

\section{Transport Resulting from Human Activities}

Personnel and vehicular traffic may account for some transport. Personne 1 and equipment surveys prior to exiting controlled contamination areas minimize the significance of this mechanism. Also, the use of containments during operations with contaminated equipment prevents the spread of loose contamination and the subsequent transport out of controlled areas.

Some evidence of each of these transport mechanisms has been found over the years within the 200 Areas. However, the monitoring programs. used within the 200 Areas and outside of the 200 Areas have shown that: (1) within the 200 Areas, concentrations of radioactivity detected in the atmosphere continue to be a small fraction of the permissible concentrations for occupational workers; (2) external radiation levels outside of posted and controlled radiation areas are such that no employee could reasonably receive any exposure in excess of the permissible dose for an individual in the general populace; and (3) Hanford operations caused no distinguishable impact on concentrations of airborne radionuclides or on external radiation dose measured off the Hanford Site. 


\section{THIS PAGE}

\section{WAS INTENTIONALLY \\ LEFT BLANK}


RHO-CD-648, REV 1

4. TECHNICAL APPROACH

This section describes the technical approach to be utilized for activities within the scope of the radiation area reduction plan. The objective of the approach is to allow the radiation area reduction $p l a n$ to be divided into manageable and controllable activities. There are four basic radiation area reduction alternatives available. These alternatives are:

Continued Routine Site Surveillance and Maintenance

Reduction or Elimination of Effluent Discharges

Improved Site Stabilization

Site Removal.

The Continued Routine Site Surveillance and Maintenance alternative stipulates that no facility modifications are required to satisfactorily maintain the site or to release it to an uncontrolled status. In this case, continued routine surveillance will be maintained to ensure that conditions affecting safety and environment do not change. 'The Reduction or Elimination of Effluent Discharges alternative may require the revision of current operating practices, improved effluent treatment, and upgraded monitoring devices for liquid, gaseous, and particulate discharges. The Improved Site Stabilization alternative will require facility improvements to reduce potential radionuclide transport or migration, but generalily the contained radionuclide inventory will not be disturbed. The Site Removal alternative will require removal of all or a large portion of the radionuclide inventory from its current location to a more suitable storage or disposal location. Any contamination remaining after removal then would be stabilized.

After an appropriate technical approach has been selected for individual facilities, scheduling of corresponding radiation area reduction activities will be based on a priority listing agreed to by Health, Safety and Environment; Research and Engineering; Production Operations; Production Support; and the Program Office. 


\section{CRITERIA AND STANDARDS}

Although radiation area cleanup has been performed in the past, there are no officially published local or national standards defining the extent to which surface soil is to be decontaminated before release from radiation area status. Work is progressing both locally and nationally to establish such standards; however, it is not expected that the task will be completed in time to be useful for the very early stages of this program. Soil decontamination criteria will be incorporated into the program planning and controls as they become available.

In the meantime, Rockwell is developing interim criteria to be used in posting areas and for releasing areas from radiation status following decontamination. These criteria will be based upon the potential for occupational radiation exposure to personnel. The surface soil contamination limits will be established with the objective of providing reasonable assurance that current radiation protection standards are not exceeded. Four basic items will be considered providing necessary personnel protection. These items and the recognized protection standards are:

- External Radiation Fields: The limits shall assure that no individual will receive in excess of 500 mrem per year from external radiation sources.

- Body Burdens of Radioactivity: The limits shall assure that no individual working or digging in. a released area will ingest or inhale radioactivity that could result in $1 / 10$ the maximum permissible body burdens specified in International Commission on Radiological Protection (ICRP) Report Number 2, Permissible Dose for Internal Radiation.

- Concentration of Radioactivity in Air: The limits shall assure that released areas do not produce airborne concentrations of radioactive materials in excess of the limits specified in DOE MC 0524, Annex A, Table II. 
Concentration of Radioactivity in Water: The limits shall assure that released areas do not result in surface water contamination in excess of the limits specified in DOE MC 0524, Annex A, Table II.

These four items of radiological control are based upon the generally accepted radiation protection standards applicable to the population at large.

It is the intent that all of the above standards will be met and that the surface soil contamination limits will be based on the most restrictive.

In developing the surface soil contamination limits, three types of contamination will be addressed: (1) contamination generally distributed through a volume of soil, (2) contamination uniformly distributed over the surface (less than 1 centimeter in thickness), and ( 3 ) individual particles of contamination distributed randomly over the surface. In deciding which type of contamination is predominant in a specific case and which standards apply, the basic intent of meeting the radiation protection requirements stated above will be considered.

For the purpose of establishing the contamination limits for the 200 Areas, the radionuclides assumed to be present in the soil are ${ }^{90} \mathrm{Sr},{ }^{137} \mathrm{Cs}$, and $239 \mathrm{pu}$. These are judged to be the major contributors and constitute the greatest hazard when ingested or inhaled.

\section{PRIORITIZATION OF RADIATION AREA REDUCTION ACTIVITIES}

The scheduling of radiation area reduction activities will be based on a priority list agreed to by Health, Safety and Environment; Research and Engineering; Production Operations; Production Support; and the Program office. The inviulale requirements for personnel, occupational and environmental safety predominate the prioritization criteria. These safety requirements will, in.turn, be supplemented by the recognized practical constraints of being unable to perform all currently identified projects immediately. The safety requirements and constraints form the criteria by which the priorities are established. 
The radiological safety criteria are based on: first, assuring the safety of employees and the generar public; second, reducing the potential for transport of radioactive material to the environment; and third, reducing radiation and contamination to ALATEP. The radiological status of the areas will be determined by scheduled radiation surveys. Other criteria which will be evaluated to establish the priority list include:

1. Utilization of available equipment, resources, and personnel.

2. Technology available to understand the long-term effects of the proposed stabilization efforts.

3. Interfaces with other programs.

4. Interfaces with ongoing soil stabilization projects and evaluations.

5. Seasonal weather considerations.

The list will be reevaluated periodically and updated as new data become available and conditions develop.

A continuing radiation survey program will provide current data for the priority list and also assure that areas which may create an immediate hazard to employees are identified and are properly controlled. If conditions which produce an immediate hazard are discovered during the surveys, prompt corrective actions will be taken. In addiliun, any new releases resulting from operations either within or outside an established area will be decontaminated promptly and methods established to eliminate any such future releases.

Multifunctional coordination meetings will be held to review progress, identify immediate response tasks and assign actions, and reevaluate the priority list in response to any new inputs. The meetings will be held by the Program Office and will be attended by Health, Safety and Environment; Production Operations; Production Support; Research and Engineering; and Quality Assurance. 
RHO-CD-648, REV 1

\section{GENERIC APPROACH}

In order to ensure consistency in radiation area reduction operations and to minimize potential redundant engineering efforts, sites have been reviewed for common characteristics and requirements and are grouped into generic categories, or activities. Detailed planning will be performed at this level.

Each generic category will have a general stabilization approach and appropriate techniques developed. Individual sites within a generic category will be characterized to establish any unique properties and requirements. Specific actions for an individual site will be developed based on its requirements in a manner consistent with the generic approach and operational procedures developed as required. These categories are defined below:

\section{Radiation Area Reduction Activities}

\begin{tabular}{cl} 
Activity Number & \multicolumn{1}{c}{ Description } \\
I. & Reduction of Dry Surface Areas \\
II. & Reduction of Wet Surface Areas \\
III. & Reduction of Tank Farm Areas \\
IV. & Reduction of BC Cribs and Control Zone \\
V. & Reduction of Storage Areas \\
VI. & Technical Support
\end{tabular}

Each generic category or activity pertains to groups of sites with similar physical conditions requiring similar treatments. The tank farms, $B C$ Cribs and control zone, and storage areas are identified as separate, unique activities due to the extent or type of effort. Activity VI is the technical support which is applied to all of the first five activities.

1. Reduction of Ory Surface Areas (Activity I). This activity includes all low-level waste sites, other than active (wet) ponds and associated ditches; $\mathrm{BC}$ Cribs, wet trenches, and control zones; tank farms; and storage areas. The types of sites that are considered include 
ial grounds; silo/caissons, dry trenches, cribs, ditches, french ins, pits, retired (dry) ponds, dry retention basins, and unplanned ease sites.

Generally, all of these sites exhibit some or all of the following iditions: Dry surfaces, subsurface and/or surface contamination, plant lionuclide uptake, animal action, wind erosion, subsidence and human ivities. Three of the four basic alternatives available for radiation a reduction are applicable to dry surface areas. They are continued itine surveillance and maintenance, improved site stabilization and e removal.

Below is a discussion of these alternatives as they apply to Reducin of Dry Surface Areas.

- Continued Routine Surveillance and Maintenance - Dry Surface Areas

This action is required on all dry surface area sites prior to the execution of one of the other alternatives. This alternative, if selected, indicates that a particular site can be maintained within the release criteria.

- Improved Site Stabilization - Dry Surface Areas

Biobarriers. Biobarriers are defined as a subsurface layer of material placed in a contaminated site to reduce the migration of radionuclides from a subsurface zone of contamination to the surface. Biobarriers, depending on the type of material or technique used, are designed to provide an improved level of control over plant uptake, weather-caused migration, animal intrusion, and human activities.

a. 10-mil polyethylene: The use of 10-mil polyethylene sheeting as a subsurface biobarrier material is directed at reducing root penetration into buried waste zones and eliminating vertical moisture movement. Placement of the 
barrier is straightforward and consists of laying overlapping sheets on a clean sand bed. Care must be taken during backfilling, to avoid damage, as the material has relatively poor strength character istics. This material is applicable to all subsurface waste sites. The installation also aids in surface revegetation by retaining soil moisture above the barrier for use by short-rooted plants.

b. Herbicides: The use of subsurface layers of herbicides provides an effective means for controlling deep root penetration. The effectiveness, however, is currently limited to only short-term applications due to the chemical dissipation. Herbicide barriers are easy to apply, usually placed as a layer in granular form, and will generally be applied to all sites using the plastic barrier sheeting. An important consideration that must be examined before applying a specific herbicide is the possible effects on revegetation efforts. Care must be taken to ensure that the herbicide is either nontoxic or isolated from desirable vegetation. This will be accomplished, in part, by placing it beneath the plastic barrier and/or using selective herbicides.

c. Cobbles (6-Inch Layer of 3/4-Inch Aggregate): This type of biobarrier is useful as a deterrent to small burrowing animals. A 6-inch layer of 3/4-inch aggregate is considered to be the minimum thickness and aggregate size to provide an effective barrier. The application will be limited to sites having burrowing animal intrusion problems due to the large quantities of import material required for this technique. The need for such a barrier as a part of stabilization will be carefully considered since nominally 2 feet of clean fill will be required to provide sufficient depth to restrict intrusion by small 
animals. Large burrowing animals, such as badgers, are not expected to be controlled by a cobble layer less than several feet thick.

d. Wire Mesh: Wire mesh, such as that used in fencing, placed as a subsurface barrier provides an effective barrier against animal intrusion. Mesh will be considered for controlling small and/or large burrowing animals. Corrosion of the material in a subsurface environment will be the limiting factor which determines the effective iife of this barrier. Application would be similar to that of plastics and consists of fastening together successive strips of the material. This type of barrier is applicable to all subsurface waste sites where root penetration and vertical moisture movement is not a problem.

Surface Stabilization. Several surface stabilization alternatives are currently available which can provide improved levels of control over plant uptake, animal action, intrusion, wind, erosion, subsidence, and human activities.: The. following paragraphs discuss the potential applications and limitations of those materials and techniques currently available for surface stabilization applications.

a. Revegetation: Revegetation as a surface treatment will be used to provide erosion control and to reduce the numbers and penetrating ability of undesirable deep-rooted species. Revegetation has been utilized to some extent with varying degrees of success during the past. 10 years. Current methodulogies using cheatgrass and to a lesser extent Siberian wheat are expected to yield successful revegetation in 1 to 4 years. Revegetation is limited to the fall planting season and requires: the use of special mulching equipment to achieve a high rate of success. Revegetation 
is applicable to all dry, decontaminated, and stabilized sites not subject to routine traffic or heavy equipment activities. Maintenance such as chemical stabilization or reseeding may be required as a result of episodic events such as drought or fire.

b. Rock Covers: A surface rock cover treatment will provide effective erosion control, and when combined with regular surface application of herbicides, will control root penetration. Rock covers have been used on a number of occasions in past stabilization activities, and observations indicate that tumbleweeds rapidly inhabit the area if surface herbicide applications are not maintained. Indications are that some local animal populations may decrease while others increase, depending on specific site conditions. This treatment is applicable to all dry surface areas that have been decontaminated and stabilized and where erosion control is required. This treatment is relatively easy to apply, but requires a large quantity of material.

c. Hard Surface Cover: A hard surface cover is a layer of hard material (e.g., asphalt pavement) placed on the surface over a waste site. Applications of such a surface would provide relatively maintenance-free control of biological transport, erosion, human activities, and subsidence damage. The extent of maintenance required for a hard surface cover is directly related to the surfacing material and loading to which the surface is subjected. The only material currently considered for application is asphalt pavement similar to that used in roads or parking lot construction. Two problems exist with the application of this alternative. First of all, it is considerably 
more expensive than the other surface stabilization techniques. Secondly, the site surface must be stable to allow access for the paving equipment. This treatment will be used in limited cases only.

d. Vegetation Control: Several forms of vegetation control are currently available. Herbicides will be applied for vegetation control in both dry and wet surface areas. In dry areas, selective herbicides will be used to control undesirable vegetation such as tumbleweeds.

- Site Removal - Dry Surface Areas

The third alternative available for the reduction of dry surface radiation areas is removal and subsequent disposal of the contaminated material. Although site removal is certainly an available alternative, the costs and environmental exposure hazards associated with the removal operation must be compared to the long-term risks and benefits. Application of this technique normally will be 1 imited to small areas of shallow surface contamination that can be handled easily or that are required to accomplish objectives. Stabilization of any residual contamination will be required following site removal. Techniques currently available for site removal operations are (a) the front loader and dump truck method, (b) the manual shovel and bucket method, and (c) the mobile mini-vacuum system.

a. Front Loader and Dump Truck Method: This method consists of removing contaminated soil using a front end loader and placing the soil in a dump truck for transport to a burial site. This is the most efficient method, as relatively large quantities of material can be moved in a short period of time. However, resuspension and spillage limits activities to low wind days and requires special handling and transportation procedures. 
b. Shovel and Bucket Method: This method consists of manually removing contaminated soil with shovels and placing it in bags or buckets for transport to a burial site. This method is useful only for very small areas, as it is very labor-intensive and only small quantities of soil can be removed. Here again, hazards due to possible resuspension and spillage are problems compounded by the fact that personnel must work in close proximity to the contaminated soil. Again, special procedures and protective clothing are required.

c. Mobile Mini-Vacuum System: The mobile mini-vacuum system, which should become operational during FY 1979, is capable of removing small areas of contaminated surface soil of the same magnitude as the shovel and bucket method. The advantage of the vacuum system is that contaminated soil is selectively picked up and immediately contained within a. 55-gallon drum for direct disposal, greatly reducing the possibility of resuspension or spillage during the operation.

2. Reduction of Wet Surface Areas (Activity II). Wet surface areas include those sites currently receiving or containing liquid waste, such as ponds and associated ditches, and exposed retention basins (also referred to as holding ponds).

The current potential transport problems at these sites are primarily the result of attractiveness of standing water and vegetation to wildlife. Various species may utilize these areas for drinking, forage or habitat, as well as a source of building materials such as vegetation or mud for the construction of nests. This problem is confused by the beneficial effects of molsture and vegetation for stabilizing contaminated pond bottoms and banks. generally found in these sites. Therefore, any potential radiation area reduction actions must consider both of these factors. 
RHO-CD-648, REV I

Applicable techniques are discussed below.

All four of the basic radiation area reduction alternatives are licable to wet surface areas.

- Continued Routine Surveillance - Wet Surface Areas

This alternative is required on all sites to verify the level and nature of contamination.

- Reduction or Elimination of Effluent Discharges - Wet Surface Aress

This action will reduce the buildup and spread of contamination at disposal sites by reducing or eliminating the source of discharge. Continued discharge of contaminated effluents within maximum permissible concentration limits can eventually lead to a buildup of contaminated soils and sediments exceeding the limits. Reduction in volume and concentration of facility effluents will significantly decrease the rate of contamination buildup.

Investigations will be made to study liquid-effluent reduction by application of established methods of industrial and municipal waste water treatment such as flocculation, sedimentation, filtering, and ion exchange. Advanced filtration methods such as ultra-filtration or reverse osmosis will also be investigated in addition to recycling of process and cooling water through closed-loop systems.

- Improved Site Stabilization - Wet Surface Areas 30-45 Mil Reinforced Pond Linings. This type of material is commonly used in many industrial waste applications. Though primarily used to control seepage, these materials also control root penetration and provide some deterrent to small burrowing animals. Pond linings are considerably more expensive than the 10-mil polyethylene, and their use will be limited to those cases where the cost/benefit considerations require a longer assured biobarrier lifetime. 
Rock Covers. A rock cover used as a surface treatment will provide effective erosion control, and when combined with regular surface application of herbicides, will control root penetration. Rock covers have been used and observations indicate tumbleweeds rapidly inhabit the area if surface herbicide applications are not maintained. (Indications are that some local animal populations may decrease while others increase; however, this depends on site conditions.) This treatment is applicable to banks of ponds, is relatively easy to apply, but requires a large quantity of material.

Exclusions. Several forms of exclusions are available to physically limit the intrusion of animals into areas. Exclusion fences will be considered for placement around the ponds and ditches to limit the intrusion of some types of mamals. Exclusion mesh will be considered for installation over small facilities such as holding ponds, retention basins and liquid effluent release points to limit the intrusion of birds. Chemical or electronic deterrents currently on the market will also be investigated for short-term usefulness in small areas. The applicability of exclusions will be limited, as routine maintenance will be required to maintain effectiveness.

Vegetation Control. Herbicides will be applied for vegetation control in selected wet surface areas. Application will disrupt the food chain established at the sites and thereby reduce the attractiveness of the site to wildlife. However, the use of these techniques must be carefully evaluated as new problems of an equal or more serious nature may actually be created. For example, while pond or ditch bank vegetation may be attractive to wildlife, it also serves to stabilize the soil. Elimination of bank vegetation without also providing a soil stabilization program may result in replacing a relatively minor biological transport problem with a more serious atmospheric transport problem. Also, herbicide applications 
once begun must be maintained or undesirable vegetation will rapidly return to the area. Vegetation control as an independent technique will have limited applicability due to the high maintenance requirements.

Pond Modifications. Modification of the configuration or complete elimination of the ponds and ditches associated with the 200 Areas will be used selectively to decrease the attractiveness of these facilities to wildlife. The fact that ponds tend to have large areas of shallow standing water (less than 2 feet deep) and gently sloped banks (less than 45 degrees) contributes significantly to the likely occurrence of radionuclide transport events. Shallow standing water and gent ly sloped banks allow attractive vegetation to become established in these areas and al.so allows water. fowl access to pond bottom sediments, where the first few inches contain most of the radionuclide inventory of ponds. If, however, the ponds are modified to maintain water levels of greater than 1 meter and have banks of 1 arge rock or concrete rubble at a slope greater than 60 degrees, they are no longer attractive for animal habital or intrusion. Modifications will be considered where ponds and ditches must remain wet and are fairly large in extent.

3. Reduction of Tank Farm Areas (Activity III). Ail 200 Area Tank rms will be considered within the Reduction of Tank Farms Activity. is includes contaminated soil and contaminated storage areas as well as intenance and/or construction actions that may expose or disturb cullnination within the tank farms. Current conditions within the tank rms include potentially resuspendable surface contamination, storage of ntained contaminated equipment, maintenance/construction activities thin tank farms, and potentially contaminated effluents resulting from nk farm operations. Periodic applications of herbicides in the tank rms maintain these areas free of vegetation and significant animal 
intrusions have been reported. Prevention of further spread of contamination will be exercised through the use of containments, strict access control, and the incorporation of step-off areas during ingress and egress to control contamination migration via protective clothing.

Long-term alternatives for tank-farm surface stabilization are being developed. Alternatives being considered include removal of some surface soil, installation of clean material (e.g., asphalt or grass cover), or a combination.

1 Interim actions for tank farm are identified below:

- Continued Routine Surveill lance - Tank Farms

This alternative is required on all tank farms.

- Improved Site Stabilization - Tank Farms

Removal of Contaminated Stored Equipment. Contaminated equipment stored in tank farms of ten is wrapped in plastic which can deteriorate in time and be transported by the wind. Storage containers are being fabricated for use in the tank farms to reduce the effect of plastic deterioration and reduce any subsequent spread of contamination.

Clean-Up of Tank Farm Areas. Surface contaminated materials which are the secondary source of transported radionuclides are being cleaned up and removed where practicable. Improved tank farm operating procedures will substantially reduce the incidence of contamination spread to articles in the farms.

Soil Stabilization. Chemical soil stabilizers are being evaluated for effectiveness for wind erosion control. Such agents will be utilized where appropriate to minimize airborne transport from the tank farms.

4. Reduction of BC Cribs and Control Zone (Activity IV). The $B C$ Cribs commonly refers to a collection of cribs and trenches located outside and directly south of the 200 East Exclusion Area. The associated control zone is an area of approximately 4 square miles that has 
:ome contaminated as a result of past biological transport from enches in the $B C$ Cribs areas. This contiguous area will be considered the $\mathrm{BC}$ Cribs and Control Zone Activity.

Current conditions within the cribs, trenches, and control zone isist primarily of surface contamination resulting from past biological :rusion and transport. However, plant uptake, animal action, subsid$: e$, wind erosion; and human activities have been observed to some tent in the $B C$ Cribs and control zone. The same alternatives will be ilized as discussed under Dry Surface Areas.'

5. Reduction of Storage Areas (Activity. $V$ ). Contaminated equipment materials placed temporarily in outdoor storage are considered in the Juction of Storage Areas Activity. For example, internally contamited railroad cars and other large pieces of equipment have been itained and stored in above-ground outdoor radiation areas. This dipment will be transported for disposal in burial grounds, and the rrounding surface areas decontaminated as necessary and released from. fiation area status. Current conditions within these storage areas zlude potentially resuspendable contamination, leakage, animal action, 1 human activities.

6. Technical Support (Activity VI). This Activity provides for aluation and implementation of new or existing radiation area reduction chnology. The developmental efforts will include tests performed under eld conditions. Those techniques that prove effective would be implented into the radiation area reduction operations with ongoing aluation of the results. Additionaliy, development of applicable criria, site characterization, and other technical support efforts are uvided.

Engineering evaluation of current site conditions is needed to bet$r$ define transport mechanisms as they relate to specific sites. The sic radiological transport mechanisms (i.e., wind, plants, animals) ve previously been identified and studied in general and on a few lect sites. This work needs to be updated and applied to existing 
radiation areas to determine which mechanisms predominate. Such information is needed to determine the optimum methods for radiation area reduction. Additional information will be gained from radiological surveys; samples of soil, vegetation, and water; and monitoring of animals and studies of ecosystems. Development of improved methods of biomonitoring also may be appropriate to aid in gathering this type of data.

Radiological surveys will be performed in support of all radiation area reduction activities. These surveys will be used to: characterize the site prior to initiation of operations, monitor progress, provide personnel exposure safety, and ensure release criteria have been achieved upon action completion. Establishment of radiological survey requirements for radiation area reduction actions will be performed by Environmental and Occupational Safety.

All applicable data will be compiled and maintained to provide records of all data generated during radiation area reduction activities. This includes data pertaining to site characterization, radiation area reduction actions, and site status data before, during, and after radiation area reduction activities. Records of these data shall be maintained to allow complete and easy access for future reference.

\section{SPECIFIC ACTION PLANS}

\section{Introduction}

Radiation area reduction and contamination cleanup work has begun in several areas. Field work is progressing on the laundry ditch berm, burial ground stabilization, tank farm cleanup, tumbleweed removal, posting and cleanup of contaminated areas, and radiological surveys.

\section{Near-Term Field Work (6 Months)}

1. Burial Grounds. The 200 East and 200 West burial grounds to receive initial action have been selected (218-E-12A and 218-W-2A), boundaries identified, access roads stabilized. to provide vehicle and personnel entry, trenches characterized, and stabilizaton initiated. 
RHO-CD-648, REV 1

During the last half of FY 1979, general housekeeping will be perrmed on the 600 Area solid waste burial grounds under Rockwell's sponsibility. Additionally, a diversion bank will be placed above the 8-2 and 618-3 Burial Sites to prevent erosion due to rain run-off from e paved areas inside the 300 Area fence onto the surface of the burial ound. Also, the 618-8 site, which is located beneath the north parking $t$ in the 300 Area, will have rain run-off trench modified to prevent anneling of the water onto the burial ground.

2. Laundry Ditch Berm. Cleanup of contaminated sediment which has ilt up along the 216-U-14 Laundry Ditch was started May 1, 1979, with e first 350 feet of berm scheduled to be removed and buried by ne 30,1979 . The entirety of the berm will be removed up to th Street, then the efforts will leapfrog to the 16 th Street region to abilize areas near the evaporator.

3. Survey Items. Radiological surveys and audits will be conducted utinely within tank farms, burial grounds, and around suspected contamation sources. Surveys will also be made routinely near facilities, rking lots, and roadways. Any items requiring corrective action wili resolved. A prioritized list of survey items for both tank farms and neral areas has been developed and schedules prepared. Approximately 0 tank farm audit items have been cleaned up and resolved during June. rk in tank farms resolving survey items will continue throughout 1979, will general survey. items and posting outside the tank farms. When rk forces are hindered from doing other scheduled work due to wind locity exceeding maximum criteria, or other reasons, they are assigned working off the backlog of survey items.

4. BC Cribs. Efforts will begin on the cleanup and stabilization the $B C$ Cribs and trenches. Current estimates forecast $50 \%$ of the cess roads between the trenches stabilized by the end of FY 1979. 
Near-Term Engineering and Health, Safety and Environment Support (6 Months)

The near-term engineering support for radiation area reduction consists primarily of reviewing past experience and results of research work currently underway, and then selecting the best solution for corrective actions.

1. Pond Management. Past pond management practices have been oriented toward preventing spread of contamination from pond sediment by maintaining water levels such that contaminated sediments are not exposed to possible wind transport. Transport due to migratory water fowl has not historically been considered a pathway of relative hazard to man. However, recent studies and new or proposed Environmental Protection Agency radiation limits indicate improved pond management practices should be reviewed. A general Pond Management Practices study will be completed, with the objective of identifying, evaluating, and recommending improved pond management techniques. These techniques would then be implemented at $U$ Pond $(216-U-10), B$ Pond $(216-B-3)$, and Gable Mountain Pond (216-A-25), as applicable. Such techniques will address bank vegetation control, aquatic vegetation control, animal control, bird and water fowl control, and stabilization of exposed sediments.

2. Laundry Facility Effluent Treatment Upgrade. An engineering study will be developed to upgrade the 1 aundry effluent treatment systems. This engineering study will support a FY 1980 General Plant Project. An additional engineering study will be initiated in FY 1979 to evaluate longer-term laundry upgrade requirements for incorporation into a possible FY 1982 line item. This study will include radiological controls within the laundry, receipt and inspection of laundry, further effluent control treatment, and space utilization.

3. Rodent Control. General rodent control measures are being initiated as a result of finding contaminated rodent feces in the 200 Arèas. While this has not posed a personnel hazard, the potential exists for 
itaminated fecal deposition in inhabited areas. The rodent control isures are being evaluated to reduce or eliminate rodent populations ;ide 200 Area buildings.

4. Z-19 Ditch. The ambient air sampler at the 216-Z-19 Ditch has JWn alpha radiation levels above maximum permissibie concentrations at -ious times. This is believed to be due to surface exposure of connination. Additional sampling and evaluation of the radiological Iditions in and around the ditches will be made to establish the scope the problem. Corrective actions then will be developed.

5. Surface Stabilization Techniques. Numerous chemicals have been sposed for possible field use as surface stabilizers to prevent windrne spread or vehicular pickup of contaminated soil. These chemicals 11 be tested outside radiation areas, for effectiveness and durabil$y$, prior to radiation area application. Tests involve applying the abilizing agent to a test plot, placing a closed box over a portion of e plot, and pulling a high-volume air sample across the surface. The $r$ sample will be filtered, and the sample filter weighed. Mass loading the filter will be a gross indication of the effectiveness of the abilizing agent. Tests will be repeated at intervals to determine abilizing agent degradation with age and environmental exposure. sults then will be used to prepare step-by-step procedures for field plication.

6. Herbicides. Use of herbicides is currently limited to soil erilant application to prevent vegetation growth in selected radiation eas such as tank farms, BC Cribs, and certa'in burial grounds. Expanded $e$ of herbicides has been considered in the past to eliminate tumbleweed owth on a much larger scale. Englneering evaluations of herbicides 11 be carried out in the second half of FY 1979 to develop a plan of tion for tumbleweed control.

7. Rad10logical Audit Surveys. Extensive radiological audit surys will be conducted within the 200 Areas. The schedule for routine dits. is shown in Section 5 of this report. Based on the results of 
these surveys, an appropriate generic approach will be selected and applied on a case-by-case basis. These actions may include one or more of the following:

- Identify and eliminate primary source of contamination and document condition.

- Cleanup by hand (bucket and shovel) areas having a limited number of particles of contamination.

- Cleanup by mechanized equipment areas having extensive contamination and document cleanup efforts.

\section{Long-Term Field Work (6 Months and Beyond)}

Radiological surveys and audits will continue so as to identify primary sources and extent of contamination and to verify clean areas. Operations crews will clean up and/or post areas as appropriate to support identified audit actions. Improved methods for biotic transport control will be studied for potential application. Rodent control will continue within facilities. Engineering support for planning, procedure development, safety assessments, design and specification development will be provided to support burial grounds, tank farms, cribs, laundry effluent control and monitoring, ditches, and other facilities.

Evaluations of relative action priorities will be made in order to assign available equipment judiciously. Where conflicts between potential uses of personnel and equipment exist, cleanup actions having the highest environmental and safety hazards will be given the highest priority. As operational activities within single-shell tank farms are reduced and completed, tank farm cleanup and stabilization action will be acceler ated.

General support to the radiation area reduction projects will be provided in the form of preparation of specific plans, procedures, and safety analyses; performance of document reviews; and the design and fabrication of field support tools, equipment, and survey instruments. A file containing photographs and characterization data for the individual 
RHO-CD-648, REV 1

:es will be developed and facility drawings will be updated. Design, irication, and/or procurement of a portable vacuum cleaner and other ccial equipment required to stabilize contaminated outdoor sites will performed, as well as the preparation of engineering and research :ommendations for methodology, prioritization, and implementation of :face stabilization and revegetation efforts.

A detailed specific action plan for the following period will be leloped and issued as part of the update to this plan. This updated redule will be based on accomplishments and on the results of radiologe al surveys. 
RHO-CD-648, REV 1

5. SCHEDULES

This section consists of oversize charts showing radiation area reduction scheduling. 
THIS PAGE

\section{WAS INTENTIONALLY \\ LEFT BLANK}


RHO RADIATION AREA REDUCTION FLAN

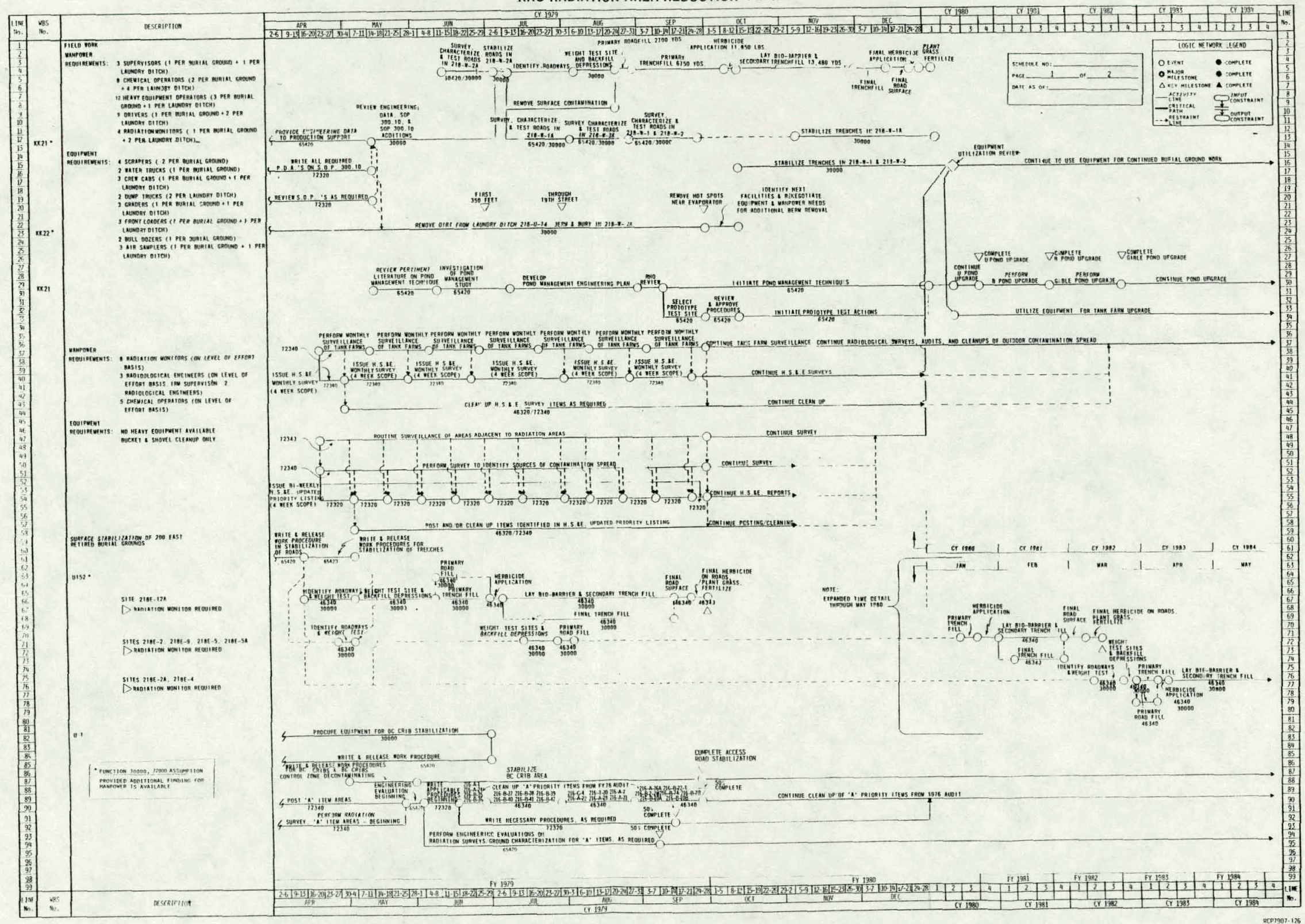




\section{RESOURCE PLANNING}

\section{HEAVY EQUIPMENT UTILIZATION}

Since the early beginnings of operations in the 200 Areas, various pieces of heavy equipment have been used on a continuous basis in supporting radiological control and cleanup operations. Heavy mobile equipment has been used in the past 2 years to clean up many small areas that were determined to be retired or inactive. In addition, plans were made during the past 2 years to increase the number of heavy mobile units to begin work on larger cleanup projects, starting in 1979.

Each piece of heavy equipment is scheduled in support of project work, on a weekly basis, to gain maximum usage and efficiency relative to the various stages of completion on each project work plan.

In the next 5 years, additional equipment needs will be identified and many of the units now in service replaced, due to those units having completed their useful life expectancy.

EXPENSE FUNDING PLAN

Expense funding for radiation area reduction is provided by three end functions:

$$
\begin{array}{ll}
\text { JM-05-01-01-2 } & \text { Waste Concentration } \\
\text { JM-05-01-01-5 } & \text { Low-Level Waste } \\
\text { AG-70-01-01-0 } & \text { Surveillance and Maintenance of Surplus } \\
& \text { Facilities }
\end{array}
$$

The specific amounts of funding within each end function which has been allocated to radiation area reduction efforts are given in Table 1. 
TABLE 1. Expense Funding Plan.

(Doliars in Thousands)

\begin{tabular}{|c|c|c|c|c|c|c|c|}
\hline \multirow{2}{*}{ End Function/Activity } & \multicolumn{7}{|c|}{ Fiscal Year } \\
\hline & 1979 & 1980 & 1981 & 1982 & 1983 & 1984 & 1985 \\
\hline
\end{tabular}

JM-05-01-01-2

KF - Waste Concentration

KF6 - Radiation Feduction and Cleanup

JM-05-01-01-5

KK - Low-Level Waste

KK2 - Radiation Area Control

$\begin{array}{lllllll}729 & 1,5 \leftleftarrows 3 & 2,482 & 2,600 & 2,800 & 2,800 & 3,000\end{array}$

$\underline{A G-70-01-01-0}$

UI - Surveillance and Ma-ntenance of Surplus Facilities*

$\frac{553}{\$ 1,282} \frac{1,4016}{\$ 3,167} \frac{3,076}{\$ 5,858} \frac{3,244}{\$ 6,144} \frac{3,328}{\$ 6,678} \frac{3,719}{\$ 7,069} \frac{4,044}{\$ 7,594}$

* Spread among four activities, U11, U12, J15, and U16. A portion of the activity funding goes toward C\&D program management and surveillance and is not included herein for radiation area reduction planning. 
RHO-CD-648, REV 1

\section{CAPITAL FUNDING PLAN}

All capital funding for radiation area reduction is provided by 35-JM-05, Defense Waste Management. This funding category is further divided into several subcategories, of which two (Programmatic and Transportation) provide capital equipment in support of radiation area reduction. Specific programatic capital funding plans are contained in Table 2. 
TABLE 2. Capital Budget Plan, Equipment Not Related to Construction.

(Collars in Trous ands)

\begin{tabular}{|c|c|c|c|c|c|c|c|}
\hline \multirow{2}{*}{ Description } & \multicolumn{7}{|c|}{ Fiscal Year } \\
\hline & 1579 & 1980 & 1981 & 1982 & 1983 & 1984 & 1985 \\
\hline Portable Vacuum Cleaner (3) & $\$ 12$ & $\$ 6$ & & & . & & \\
\hline Herbicide Applicator Equipment & & 20 & & & & & \\
\hline Garbage Truck Compactor & & 60 & & & & & \\
\hline 10-Yard Dump Trucks (6) & & 150 & $\$ 150$ & & & & \\
\hline Front Loaders & & 80 & & & $\$ 40$ & & \\
\hline 4-Yard Payloader & & & & $\$ 20$ & & & \\
\hline Road Grader & & & 210 & & & & \\
\hline Flatbed Truck & & & 35 & & & & \\
\hline Belly Loader (20-Yard Capacity) (3) & & $20 \mathrm{C}$ & 400 & & & & \\
\hline Buck Rake & & & 23 & & & & \\
\hline Dragline Bucket & & & 12 & & & & \\
\hline Water Truck (2) & & 40 & & & .190 & n & \\
\hline Four-Wheel Drive Pickups (3) & 10 & 10 & 10 & & & & \\
\hline Crew Cabs (3) & & 20 & 10 & & & . & \\
\hline Fertilizer Spreader & 3 & & & & & & \\
\hline Trailer-Mounted Str $=$ w MuTcher & & 15 & & & & & \\
\hline Sheep's Foot Packer & & 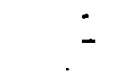 & & & & & \\
\hline D-8 Caterpillar & & 200 & & & & & \\
\hline 1- by 40-foot Change Trailer & & & & 40 & & & \\
\hline D-4 Caterpillar & & & & & $\$ 105$ & & \\
\hline Field-Test Equipment & & & 30 & 20 & 100 & & \\
\hline Replacement Equipment & - & - & 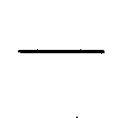 & 75 & - & $\$ 60$ & $\underline{\$ 58}$ \\
\hline TOTAL & $\$ 25$ & $\$ 80 ?$ & $\$ 880$ & $\$ 155$ & $\$ 435$ & $\$ 60$ & $\$ 58$ \\
\hline
\end{tabular}


RHO-CD-648, REV 1

\section{MANAGEMENT AND CONTROL}

This section highlights portions of the Rockwell Management Control System (MCS), RHO-MA-141, especially applicable to Radiation Area Reduction, and delineates specific authorities and responsibilities. All activities carried out as part of this plan are conducted in accordance with approved Rockwell policies, procedures, specifications, and manuals.

PROGRAM MANAGEMENT ANO CONTROL .

A11 Rockwell Directors are required to carry out their programs and operations in a safe and cost-effective manner, and in accordance with approved regulations and policies. As such, each Director has responsibility to assure that current operations do not contribute to the generation of new radiation areas, and that every effort possible is made to reduce existing areas.

The activities discussed in this plan integrate, coordinate, and organize Rockwell's approach to the reduction of radiation areas within the 200 Areas and in specifically designated 600 Area sites. The Program Director for Waste Management has overall Rockwell programatic responsibility and authority for the conduct of the program. This direction consists principally of establishing program and management policy, funding allocations, overall priorities, and specific milestones and goals. The Program Uirector will be responsible for overall schedule and cost. control.

Two primary DOE-RL program funding sources are utilized for radiation area reduction activities. They are JM-05, Defense Waste Management, and AG-70, Decontamination and Decommissioning. Within these two funding sources, three specific end functions participate in radiation area reduction activities. They are:

$\begin{array}{ll}\text { JM-05-01-01-2 } & \text { Waste Concentration } \\ \text { JM-05-01-01-5 } & \text { Low-Level Waste } \\ \text { AG-70-01-01-0 } & \text { Surveillance and Maintenance of Surplus } \\ & \text { Facilities }\end{array}$


The first two of these end functions are under the overall program control of the Program Director for Waste Management, and the third (AG) is under the Program Director for Waste Technology, and each end function has been charged with specific areas of responsibiilty for the purposes of radiation area reduction. The Program Director for Waste Management will have overall Rockwell radiation area reduction project control.

The Waste Concentration Program is responsible for radiation reduction activities within the tank farms and associated facilities. This is done to ensure that tank farm cleanup, source elimination, and waste concentration activities are integrated and coordinated, and do not become counterproductive.

The Low-Level Waste Program has responsibility for all radiation area reduction activities not covered within the scope of either Waste Concentration or Surveillance and Maintenance of Surplus Facilities.

The Surveillance and Maintenance of Surplus Facilities has responsibility for all facilities designated as retired prior to October 1, 1976, which includes structural D\&D.

In addition to the programmatic responsibilities discussed, several functional directors play key roles in the performance of radiation area reduction plans.

Health, Safety and Environment (HS\&E)

The Director of HS\&E is responsible for overall safety criteria and standards, environmental monitoring and surveillance, and radiological surveys. Health, Safety and Environment also will be responsible for establishing and maintaining audit action lists and establishing specific radiological priorities for actions to be taken. Health, Safety and Environment will provide input for technology development and will review and approve all Work Procedures.

Research and Engineering (R\&E)

The Director of R\&E will be responsible for the preparation of engineering and supporting documents for the conduct of radiation area reduction activities. Research and Engineering also will identify the need for 
site characterization and technology development, and will carry out the required technology development. Research and Engineering will prepare, review, and approve all Work Procedures.

Production Operations

The Director of Production Operations will provide the necessary staff, including chemical operators, to implement the Radiation Area Reduction Work Procedures. Production Operations will review, approve, and utilize all Work Procedures according to the requirements of Procedures $D-4$ and D-4.2 of the Rockwell Engineering Procedures Manual, RHO-MA-115. The Director of Production Operations will be responsible for providing overall scheduling and control of all radiation area reduction field work.

Production Support

The Director of Production Support will provide the necessary equipment, heavy equipment operators, and craftsmen to implement the Radiation Area Reduction Work Procedures. Production Support will review all Work Procedures and will approve those resulting in work assignments within Production Support.

Quality Assurance (QA)

The Director of $Q A$ is responsible for providing Quality Engineering, Quality Control, and Analytical services to implement radiation area reduction operations and data management. Quality Assurance will review and approve all Work Procedures.

\section{EXECUTIVE MANAGEMENT REVIEW'}

Rockwell policy requires that all operations, functions, and programs be independently reviewed to assure that these activities are being performed in accordance with safety standards established by Rockwell. Hanford Operations, U.S. Department of Energy, and regulatory agencies. The activities described in the Radiation Area Reduction Plan will be subjected to this independent review process. Specifically, the Waste 
Processing Safety Committee will have responsibility for reviewing radiation area reduction operations for safety. This process will provide Rockwell executive management with an independent review of the activities.

\section{COST AND SCHEDULE CONTROL}

Cost and schedule control is in accordance with the Rockwell Hanford Operations Management Control System Description, RHO-MA-141. The effort performed in the Radiation Area Reduction Project Plan follows the Work Breakdown Structure of the Waste Concentration Program Plan, RHO-CD-330, Activity KF6; the Low-Level Waste Program Plan, RHO-CD-428, Activity KK2; and the Decontamination and Decommissioning (D\&D) Program Plan, RH0-CD-421, Activities U11, U12, U15; and U16.

1. Cost control for the Radiation Area Reduction Plan for FY 1979 will utilize existing Rockwell cost controls. Work packages, which are the fourth level of the Rockwell Work Breakdown Structures, will be used. Work packages will be issued to the functional organizations by the Program Office. The work package will include description of work, milestones, and target budgets consistent with each program 'plan. Each functional organization will prepare Functional. Planning Documents for each assigned work package which defines and distributes resource requirements. Any deviation from the provided.scope, milestone, and/or budget guidance will be resolved with the Program Office. Program Business Management will provide support for all phases of the budget cycle.

2. Schedule control will be in accordance with Rockwell Hanford Management Schedule System Manual, RHO-MA-123 DRAFT. The schedules included in this plan will be maintained in current status through periodic updates. Program Business Management will provide scheduling support at all levels of the schedule heirarchy, with the exception of Production Operations and Production Support, who shall furnish functional schedule support through their production control departments. The major milestones will be consistent with the Waste Concentration Program Plan, RHO-CD-330; the Low-Level Waste Program Plan, RHO-CD-428; and the Decontamination and Decommissioning (D\&D) Program Plan, RHO-CD-421. 
RHO-CD-648, REV 1

The major milestones depicted on the master program schedules will be used as key milestones on the Work Packages. These documents shall be maintained consistent throughout the fiscal year.

These same major milestones appear, and will be statused, on the Rockwell Monthly Report, RHO-LD-108, which will be the reporting document for this plan.

\section{SAFETY}

The Radiation Area Reduction Plan will be conducted in a manner so as to protect the safety and health of all employees and prevent loss or damage to any facility. All operations will be conducted in compliance with applicable health and safety requirements of the U.S. Department of Energy and will adhere to generally recognized and accepted high standards of performance in the areas of occupational health, nuclear, radiological and industrial safety, and environmental protection.

The Health, Safety and Environment organization will be responsible for ensuring that adequate safety criteria and requirements are established, and that safety audits are performed.

\section{QUAL ITY ASSURANCE}

The Quality Assurance Program that will be implemented for Radiation Area Reduction shall comply with applicable portions of Department of Energy RL Append ix 0820, paragraphs $A$ and F. The Quality Assurance organization is in accord with the organization charts contained in Rockwell Hanford Operations Policies Manual, RHO-MA-100.

The Quality Assurance disciplines applicable to Radiation Area Reduction include verification of radiological survey data, acceptance of end-point conditions, specification of acceptance criteria in specifications and instructions, assurance that operations are performed in accordance with approved Work Procedures, and records that are complete and auditable. Specific actions shall be delegated to the HS\&E function in areas where they possess the expertise, personnel, and existing recordkeeping capability. 
All work shall be performed in accordance with approved, written instructions, specifications, and drawings. Quality Engineering shall approve all procedures, specifications, and drawings. The acceptance (end-point) criteria shall be specified. Control of procedures, specifications, and drawings shall be exercised to assure only the appropriate revisions are used in the work areas. Confirmation that procedures are controlled and field work complies shall be by Quality Assurance surveill ance.

Inspection of fabricated hardware and equipment shall be performed by Quality Control. All radiological surveys and end-point inspections of completed radiation area reduction tasks shall be performed by Health, Safety and Environment. All radiological survey and end-point data shall be maintained by HS\&E. The Quality Information Center shall provide confirmation that records are maintained and are recoverable and auditable.

Adverse conditions shall be documented, investigated and corrected, through application of the Corrective Action system. This effort will prevent repetition of adverse conditions and provide more effective performance of radiation area reduction:

Formal Quality Audits will not be specifically performed for radiation area reduction. The existing audit program shall cover the disciplines involved on a 200 Area-wide basis.

SUPPORTING DOCUMENTATION AND DOCUMENT CONTROL

Supporting Documents

Each radiation area reduction activity will be further defined and developed through the preparation of supporting documents, including Activity Plans, Test Plans, Test Procedures, Work Procedures, Standard Operating Procedures, and schedules, as described in the following subsections.

1. Activity Plans. An Activity Plan defines the engineering, development, and data requirements for a specific activity. Included are assessments of available data, technology, and resources. (Note: The 
term "resources" includes funding, manpower, materials, and equipment.) Also included are detailed descriptions of the need for further characterization and technological development. All subsequent work procedures, designs, and specifications required are listed. Finally, the Activity $\mathrm{Plan}$ presents a logic network for executing the tasks described. Each of the six activities listed in Section 4 will have an Activity $P l a n$ prepared to aid in the execution of the engineering efforts.

2. Test Plans. A Test $P l a n$ is a general description of a particular type of testing required. Included are basic definitions, objectives, testing requirements, acceptance criteria, and documentation requirements. These plans will be used in the event any hardware development is required.

3. Work Procedures. Work Procedures provide detailed, step-by-step instructions necessary to perform tasks. Each Work Procedure identifies work-related hazards and includes radiological and other safety precautions.

A Work Procedure may be either specific or general. A specific Work Procedure is tailored to a specific job and is used only once. A general Work Procedure applies to a particular aspect of many different jobs and therefore can be used more than once. Within its sequence of steps, a specific Work Procedure can call for the use of one or more general Work Procedures.

4. Standard Operating Procedure. Standard Operating Procedures (SOPS) may be used in place of general Work Procedures for jobs already covered by existing SOPS.

Document Control

Release of supporting documents shall be by Engineering Order (EO) processed through the Engineering Release System, per RHO-MA-115, Engineering Procedures Manual. The release Engineering Order shall be prepared by the supporting document author, shall include a distribution list, and shall be approved in accordance with existing procedures. 


\section{RHO-CD-648, REV 1}

Distribution and control of Work Procedures and revisions/changes shall be accomplished by the Operating. Document Control Unit. Control copies are limited to the field copy and Operating Document Control copy. Other copies are for information only.

A supplement to the D\&D Document Release Plan, D00DRCP0001, will be prepared to establish the requirements for supporting document preparation, release, and control. 
RHO-CD-648, REV 1

APPENDIX

CONTAMINATED FACILITIES LIST

NOTES:

1. Status: A - Active

R - - Retired

NU - Not used; facility constructed but never used for storage or disposal of radioactivity. Not contaminated.

SB - Standby

RELEASED - Radiation area decontaminated, stabilized, and released from radiation control.

2. Total UN - Unavailable; documents not yet researched; Area (Ft2) will be developed as part of site characterization.

3. Comments: "No contamination found" indicates that no contaminated vegetation or surface contamination was detected during the most recent radiological survey.

4. Total number of facilities listed -482 . 
THIS PAGE

\section{WAS INTENTIONALLY}

\section{LEFT BLANK}


RHO-CD-648, REV 1

\section{APPENDIX}

CONTAMINATED FACILITIES LIST

\begin{tabular}{|c|c|c|c|c|}
\hline$\underline{\text { SITE }}$ & $\underline{\text { STATUS }}$ & DESCRIPTION & $\begin{array}{l}\text { TOTAL } \\
\text { AREA } \\
(\text { ft } 2) \\
\end{array}$ & COMMENTS \\
\hline \multicolumn{5}{|c|}{600 AREA SOLID WASTE DISPOSAL SITES: } \\
\hline $618-1$ & $\mathrm{R}$ & & UN & \\
\hline $618-2$ & $\mathrm{R}$ & & UN & \\
\hline $618-3$ & R & & UN & \\
\hline $618-4$ & $R$ & . & UN & \\
\hline $618-5$ & $\mathbf{R}$ & & UN & \\
\hline $618-6$ & R & & UN & \\
\hline $618-7$ & R & & UN. & \\
\hline $618-8$ & $\mathrm{R}$ & & UN & \\
\hline $618-9$ & R & & UN & \\
\hline $618-10$ & R & & UN & \\
\hline $618-11$ & R & & UN & \\
\hline \multicolumn{5}{|c|}{600 AREA LIQUID WASTE DISPOSAL SITES } \\
\hline $616-U$ & $\mathrm{R}$ & . & UN & \\
\hline
\end{tabular}


RHO-CD-648, REV 1

CONTAMINATED FACILITIES LIST (CONTINUED)

E $\quad$ STATUS
REA LIQUID WASTE DISPOSAL SITES:

TOTAL

AREA

$(f \underline{2})$

COMMENTS

\begin{tabular}{|c|c|c|c|c|}
\hline $1-1$ & $\mathrm{R}$ & Crib & 2,500 & $\cdot$ \\
\hline $1-2$ & $R$ & Crib & 1,600 & No Contamination Found \\
\hline $1-3$ & $A$ & Crib & 1,600 & No Contamination Found \\
\hline $1-4$ & $\mathbf{R}$ & Crib & 1,600 & No Contamination Found \\
\hline $1-5$ & $\mathrm{R}$ & Crib & 3,600 & No Contamination Found \\
\hline $1-6$ & $R$ & Crib & 22,500 & No Contamination Found \\
\hline $1-7$ & $\mathbf{R}$ & Crib & 400 & \\
\hline $1-8$ & $A$ & crib & 27,000 & \\
\hline $1-9 \div$ & R & Crib & 15,000 & No Contamination Found \\
\hline-10 & $A$ & Crib & 18,000 & No Contamination Found \\
\hline$[-1]$ & A & French Drain & 2 & \\
\hline $1-12$ & $A$ & French Drain & 2 & \\
\hline-13 & R & French Drain & 10 & No Contamination Found \\
\hline-14 & $A$ & French Drain & 2 & No Contamination Found \\
\hline $1-15$ & $A$ & French Drain & 2 & No Contamination Found \\
\hline $1-16$ & $R$ & French Drain & 3 & \\
\hline $1-17$ & R & French Drain & 3 & \\
\hline $1-18$ & R & Crib & 10,000 & \\
\hline $1-19$ & R & Crib & 1,600 & No Contamination Found \\
\hline $1-20$ & R & Crib & 900 & No Contamination Found \\
\hline $1-21$ & $R$ & Crib & 1,600 & No Contamination Found \\
\hline $1-22$ & $R$ & Crib & 4 & \\
\hline $1-23 A$ & $R$ & French Drain & 3 & \\
\hline $1-238$ & $\mathbf{R}$ & French Drain & $\therefore \quad 3$ & \\
\hline $1-24$ & $\mathrm{R}$ & Crib & 150,000 & \\
\hline $1-25$ & A & Pond & 2 & No Contamination Found \\
\hline
\end{tabular}


RHO-CD-648, REV 1

CONTAMINATED FACILITIES LIST (CONTINUED)

\begin{tabular}{|c|c|c|c|c|}
\hline SITE & STATUS & DESCRIPTION & $\begin{array}{l}\text { TOTAL } \\
\text { AREA } \\
\text { (ft2) }\end{array}$ & COMMENTS \\
\hline \multicolumn{5}{|c|}{200 AREA LIQUID WASTE DISPOSAL SITES: (CONTINUED) } \\
\hline $216-A-26 A$ & R & French Drain & 2 & No Contamination Four \\
\hline $216-A-26 B$ & A & French Drain & 3 & No Contamination Four \\
\hline $216-A-27$ & $\mathrm{R}$ & Crib & 6,000 & No Contamination Four \\
\hline $216-A-28$ & R & Crib & 8 & \\
\hline $216-A-29$ & A & Ditch & 195,000 & \\
\hline $216-A-30$ & A & Crib & 28,000 & \\
\hline $216-A-31$ & R & Crib & 1,600 & No Contamination Four \\
\hline $216-A-32$ & A & Crib & 1,200 & No Contamination Four \\
\hline $216-A-33$ & R & French Drain & 4 & No Contamination Four \\
\hline $216-A-34$ & R & Crib & 12,300 & No Contamination Four \\
\hline $216-A-35$ & R & French Drain & 4 & No Contamination Foul \\
\hline $216-A-36 A$ & R & Crib & 2,000 & No Contamination Four \\
\hline $216-A-36 B$ & $R$ & Crib & 10,000 & No Contamination Four \\
\hline $216-A-37-1$ & SB & Crib & 21,000 & ' \\
\hline $216-A-38-1$ & SB & Crib & 18,000 & No Contamination Four \\
\hline $216-A-39$ & $R$ & Crib & 900 & No Contamination Four \\
\hline $216-A-40$ & A & Crib & 20,000 & No Contamination Four \\
\hline $216-A-41$ & A & Crib & 400 & No Contamination Foul \\
\hline $216-A-42$ & A & Trench & UN & \\
\hline $216-A-271$ & A. & Valve Control House & 96 & \\
\hline $216-A-508$ & A & Crib Control Structure & UN & \\
\hline $216-A-524$ & $R$ & Crib Contrnl Structure & UN & \\
\hline $216-8-2$ & A & Ditch & UN & \\
\hline $216-B-2-1$ & $\mathrm{R}$ & Ditch & 210,000 & \\
\hline $216-8-2-2$ & $R$ & Ditch & UN & \\
\hline $216-B-2-3$ & A & Ditch & UN & No Contamination Fou \\
\hline
\end{tabular}


RHO-CD-648, REV 1.

CONTAMINATED FACILITIES LIST (CONTINUED)

\begin{tabular}{|c|c|c|c|c|}
\hline & STATUS & & $\begin{array}{l}\text { TOTAL } \\
\text { AREA } \\
(f+2\end{array}$ & \\
\hline & SIATOS & UESCR IPIION & & COMMENTS \\
\hline
\end{tabular}

IREA LIQUID WASTE DISPOSAL SITES: (CONTINUED)

\begin{tabular}{|c|c|c|c|c|}
\hline $3-3$ & A & Pond & $2,003,760$ & No Contamination Found \\
\hline $3-3-1$ & $R$ & Dilch & UN & . . \\
\hline $3=3-2$ & $\mathrm{R}$ & Ditch & UN & \\
\hline $3-3-3$ & A & Uitch & UN & No Contamination Found \\
\hline $3-4$ & R & Reverse Well & 1 & \\
\hline $3-5$ & $\mathbf{R}$ & Reverse Well & 1 & \\
\hline 3-6 & $R$ & Reverse We11 & 1 & No Contamination Found \\
\hline $3-7 A$ & $R$ & Crib & 400 & \\
\hline $3-7 B$ & $R$ & Crib & 400 & \\
\hline $3=8$ & $R$. & Crib \& Tile Field & 400 & \\
\hline $3-9$ & $R$ & Crib \& Tile Field & 1,300 & \\
\hline $3-10 A$ & $\mathrm{R}$. & Crib & 400 & No Contamination Found \\
\hline $3-10 B$ & $R$ & Crib & 400 & \\
\hline $3-11 A$ & $\mathrm{R}$ & Reverse Well & 6 & No Contamination Found \\
\hline$i-11 B$ & $\mathrm{R}$ & Reverse Well & 6 & No Contamination Found \\
\hline$i-12$ & $\mathrm{R}$ & Crib & UN. & No Contamination Found \\
\hline$i-13$ & A & French Drain & 3 & \\
\hline$i-14$ & $\dot{R}$ & Crib & 2,500 & \\
\hline$i-15$ & R & Crib & 2,500 & \\
\hline$i-16$ & R & Cr1b & 2,500 & \\
\hline $1-17$ & $R$ & Crib & 2,500 & \\
\hline$i-18$ & R. & Crib & 2,500 & \\
\hline $1-19$ & R & Crib & 2,500 & . \\
\hline $1-20$ & R & Trench & 15,000 & \\
\hline$i-21$ & $R$ & Trench & 15,000 & \\
\hline$i-22$ & $R$ & Trench & 15,000 & \\
\hline$i-23$ & $\mathbf{R}$ & Trench. & 15,000 & \\
\hline
\end{tabular}


RHO-CD-648, REV 1

CONTAMINATED FACILITIES LIST (CONTINUED)

\begin{tabular}{|c|c|c|c|c|}
\hline SITE & STATUS & DESCRIPTION & $\begin{array}{l}\text { TOTAL } \\
\text { AREA } \\
(\mathrm{ft2}) \\
\end{array}$ & COMMENTS \\
\hline \multicolumn{5}{|c|}{200 AREA LIQUID WASTE DISPOSAL SITES: } \\
\hline $216-8-24$ & R & Trench & 15,000 & \\
\hline $216-B-25$ & $R$ & Trench & 15,000 & \\
\hline $216-8-26$ & R & Trench & 15,000 & \\
\hline $216-B-27$ & $R$. & Trench & 15,000 & \\
\hline $216-B-28$ & R & Trench & 15,000 & \\
\hline $216-8-29$ & $R$ & Trench & 15,000 & \\
\hline $216-B-30$ & R & Trench & 15,000 & \\
\hline $216-8-31$ & R & Trench & 15,000 & \\
\hline $216-B-32$ & $R$ & Trench & 15,000 & \\
\hline $216-B-33$ & R & Trench & 15,000 & $\because$ \\
\hline $216-B-34$ & $R$ & Trench & 15,000 & \\
\hline $216-B-35$ & R & Trench & 7,800 & \\
\hline $216-B-36$ & $\mathbf{R}$ & Trench & 7,800 & \\
\hline $216-B-37$ & $R$ & Trench & 7,800 & \\
\hline $216-B-38$ & $R$ & Trench & 7,800 & \\
\hline $216-B-39$ & $R$ & Trench & 7,800 & \\
\hline $216-B-40$ & $R$ & Trench & 7,800 & . \\
\hline $216-B-41$ & R. & Trench & 7,800 & \\
\hline $216-B-42$ & R & Trench & 7,800 & \\
\hline $216-8-43$ & $R$ & Crib & & \\
\hline $216-B-44$ & R & Crib & & \\
\hline $216-B-45$ & $R$ & Crib & & Stabilized FY 1978 \\
\hline $216-8-46$ & $R$ & Crib & 64,800 & Under ECT - D\&D \\
\hline $216-B-47$ & $R$ & Crib & & Program \\
\hline $216-B-48$ & $R$ & Crib & & $\therefore$ \\
\hline $216-8-49$ & $R$ & Crib & & \\
\hline $216-8-50$ & $R$ & Crib & & \\
\hline
\end{tabular}


CONTAMINATED FACILITIES LIST (CONTINUED)

\begin{tabular}{|c|c|c|c|c|}
\hline & & & $\begin{array}{l}\text { TOTAL: } \\
\text { AREA }\end{array}$ & \\
\hline$F$ & STATIIS & DFSSRRTPTTINN & $(f+2)$ & COMMENTS \\
\hline
\end{tabular}

REA LIQUID WASTE DISPOSAL SITES: (CONTINUED)

\begin{tabular}{|c|c|c|c|c|}
\hline-51 & $\mathrm{R}$ & French Drain & 3 & \\
\hline-52 & $R$ & Trench & 18,000 & \\
\hline$-53 A$ & $R$ & Trench & 2,100 & \\
\hline$-53 B$ & $R$. & Trench & 4,500 & \\
\hline-54 & $R$ & Trench & 6,000 & \\
\hline-55 & $A$ & Crib & 7,500 & \\
\hline-56 & NU & Crib & 700 & No Contamination Found \\
\hline-57 & R & Crib & 3,000 & \\
\hline-58 & $R$ & Trench & 2,000 & \\
\hline-59 & A & Trench & 8,000 & No Contamination Found \\
\hline-60 & $R$ & Crib & 16 & No Contamination Found \\
\hline-61 & NU & Crib & 1,750 & \\
\hline-62 & $A$ & Crib & 5,000 & No Contamination Found \\
\hline-63 & $A$ & Trench & 5,000 & \\
\hline-64 & NU & Diversion Trench & 5,000 & No Contamination Found \\
\hline-1 & R & Crib & 250 & \\
\hline-2 & A & Reverse Well & 1 & \\
\hline$;-3$ & $R$ & Crib & 2,400 & \\
\hline$;-4$ & $R$ & $C r t b$ & 600 & \\
\hline$:-3$ & $R$ & Crlb & 600 & \\
\hline$;-6$ & $\mathbf{R}$ & Crib & 600 & \\
\hline$:-7$ & A & Crib & 600 & \\
\hline$:-8$ & $R$ & French Drain & 4 & \\
\hline ;-9 & A & Pond. & 80,000 & \\
\hline :-10 & $\mathbf{R}$ & Crib & 160 & \\
\hline $1-1$ & RELEASED & Pond & UN & \\
\hline $1-2$ & $R$ & Trench (backfilled) & 500 & No Contamination Found \\
\hline
\end{tabular}


RHO-CD-648, REV 1

CONTAMINATED FACILITIES LIST (CONT INUED)

SITE STATUS $\quad$ DESCRIPTION $\begin{aligned} & \text { TOTAL } \\ & \text { AREA } \\ & \text { (ft2) }\end{aligned}$

200 AREA LIQUID WASTE DISPOSAL SITES: (CONTINUED)

\begin{tabular}{|c|c|c|c|c|}
\hline $216-N-3$ & R & Trench (backfilled) & 500 & No Contamination Founi \\
\hline $216-N-4$ & $\mathrm{R}$ & Pond (covered). & 100,000 & No Contamination Foun \\
\hline $216-N-5$ & R & Trench (backfilled) & 1,200 & No Contamination Foun \\
\hline $216-N-6$ & $\mathbf{R}$ & Pond (covered) & 75,000 & No Contamination Foun \\
\hline $216-\mathrm{N}-7$ & $R$ & Trench (backfilled) & 1,200 & \\
\hline $216-5-1$ & $R$ & Crib & 3,600 & \\
\hline $216-5-2$ & $R$ & Crib & 3,600 & \\
\hline $215-S-3$ & $\mathrm{R}$ & Crib & 20,000 & No Contamination Foun \\
\hline $216-5-4$ & $\mathbf{R}$ & French Drain & 900 & No Contamination Foun \\
\hline $216-S-5$ & $R$ & Crib & 75,625 & No Contamination Foun \\
\hline $216-S-6$ & $\mathbf{R}$ & Crib & 90,000 & \\
\hline $216-5-7$ & $R$ & Crib & 30,625 & \\
\hline $216-5-8$ & $\mathbf{R}$ & Trench & $\cdot 15,000$ & \\
\hline $216-5-9$ & $R$ & Crib & 26,250 & No Contamination Foun \\
\hline $216-S-10$ & A & Ditch \& Pond & 262,800 & 0ld Redox Leach Pond \\
\hline $216-S-11$ & $R$ & Pond & 65,340 & $\begin{array}{l}\text { 01d Redox Leach Pond } \\
\text { No Contamination Foun }\end{array}$ \\
\hline $216-S-12$ & R & Trench & 5,000 & \\
\hline $216-5-13$ & $R$ & Crib & 10,000 & No Contamination Foun \\
\hline $216-S-14$ & RELEASED & Trench & UN & \\
\hline $216-S-15$ & $R$ & Pond (covered) & 750 & \\
\hline $216-S-16$ & $R$ & Ponds. (covered) & $1,384,360$ & \\
\hline $216-5-17$ & $R$ & Pond (covered) & 740,520 & \\
\hline $216-5-18$ & RELEASED & Crib & UN & \\
\hline $216-5-19$ & $A$ & Pond & 152,460 & 222-S Lab Pond \\
\hline $216-S-20$ & $R$ & Crib & 6,000 & \\
\hline $216-S-21$ & $R$ & Crib & 5,625 & \\
\hline $216-S-22$ & $\mathrm{R}$ & Crit & 5,200 & No Contamination Four \\
\hline
\end{tabular}




$$
\text { RHO-CD-648, REV } 1
$$

CONTAMINATED FACILITIES LIST (CONTINUED)

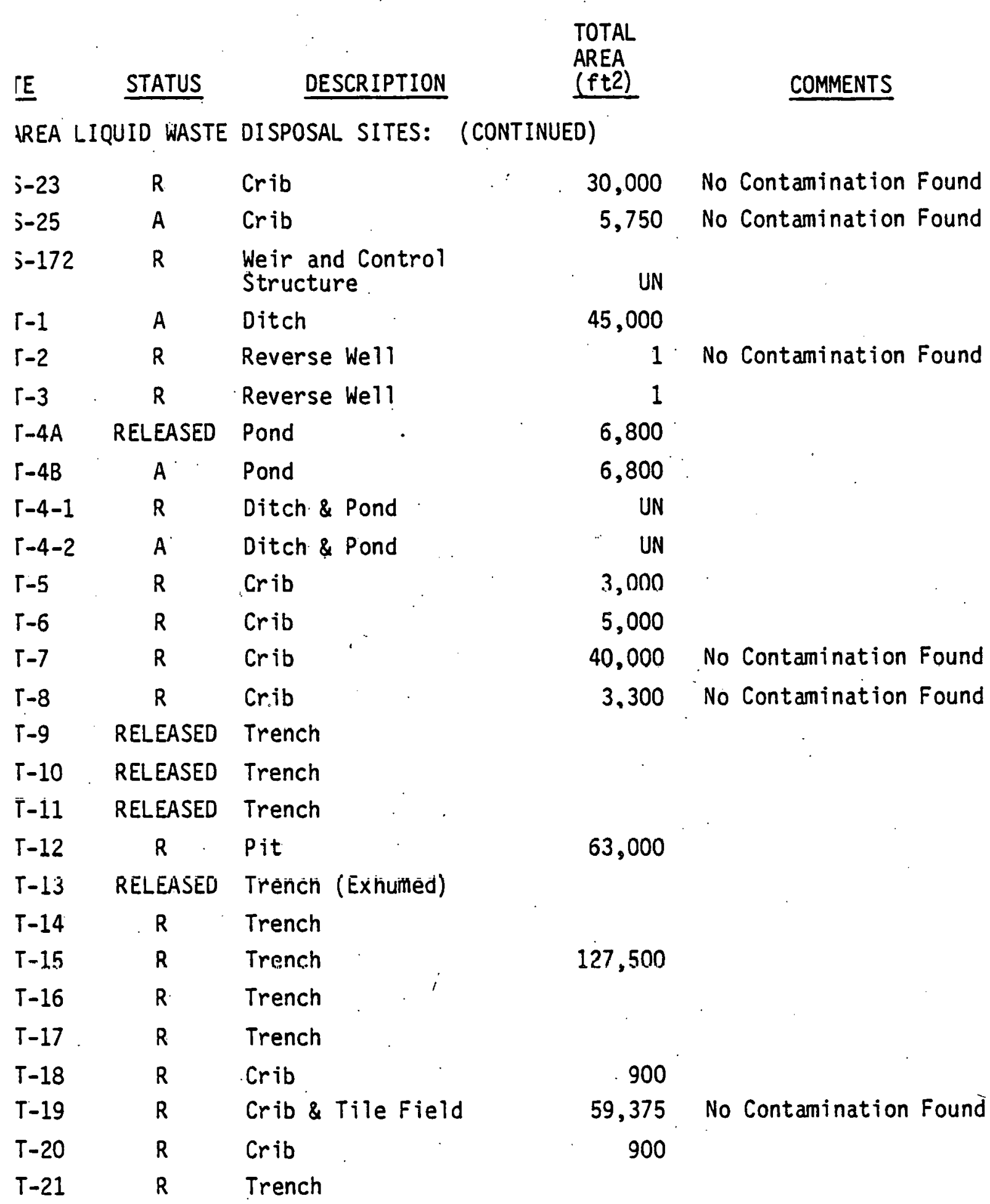


RHO-CD-648, REV 1

CONTAMINATED FACILITIES LIST (CONTINUED)

\begin{tabular}{|c|c|c|c|c|}
\hline & & & $\begin{array}{l}\text { TOTAL } \\
\text { AREA } \\
(f+?)\end{array}$ & ' \\
\hline SITE & STATUS & DESCR IPTION & $(f t 2)$ & COMMENTS \\
\hline
\end{tabular}

200 AREA LIQUID WASTE DISPOSAL SITES: (CONTINUED)

\begin{tabular}{|c|c|c|c|c|}
\hline $216-T-22$ & $R$ & Trench & & \\
\hline $216-T-23$ & $R$ & Trench & 175,000 & \\
\hline $216-T-24$ & $R$ & Trench & & \\
\hline $216-T-25$ & $R$ & Trench & & \\
\hline $216-T-26$ & $R$ & Crib & & \\
\hline $216-T-27$ & $R$ & Crib & 78,000 & \\
\hline $216-T-28$ & $R$ & Crib - & & \\
\hline $216-T-29$ & $R$ & French Drain & UN & \\
\hline $216-T-30$ & $R$ & Unplanned Release Site & 5,500 & \\
\hline $216-T-31$ & RELEASED & French Drain (Exhumed) & & \\
\hline $216-T-32$ & $R$ & Crib & 40,000 & No Contamination Fol \\
\hline $216-T-33$ & $R$ & Crib & 1,600 & No Contamination For \\
\hline $216-T-34$ & $R$ & Crib & 8,800 & \\
\hline $216-T-35$ & $R$ & Crib & 25,000 & No Contamination Fol \\
\hline $216-T-36$ & R & Crib & 20,250 & No Contamination Fol \\
\hline $216-U-1$ & $R$ & Crib & 15,300 & \\
\hline $216-U-2$ & $R$ & Crib & & \\
\hline $216-U-3$ & $\mathbf{R}$ & French Drain & 400 & No Contamination Fol \\
\hline $216-U-4$ & R & Reverse Well & 1 & No Contamination Fol \\
\hline $216-U-4 A$ & $\mathbf{R}$ & Dry Well & 2 & No Contamination Fol \\
\hline $216-U-4 B$ & $R$ & Dry Well & 2 & No Contamination Fol \\
\hline $216-U-5$ & R & Trench & 1,500 & \\
\hline $216-U-6$ & $R$ & Trench & 2,000 & No Contamination Fol \\
\hline $216-U-7$ & $R$ & French Drain & 2 & \\
\hline $216-U-8$ & $\cdot R$ & Crib & 9,500 & No Contamination Fol \\
\hline $216-U-9$ & $\mathbf{R}$ & Ditch & 48,000 & \\
\hline $216-U-10$ & $A$ & Pond & 958,320 & \\
\hline
\end{tabular}


RHO-CD-648, REV 1

CONTAMINATED FACILITIES LIST (CONTINUED)

IE. STATUS $\quad$ DESCRIPTION $\quad \begin{aligned} & \text { TOTAL } \\ & \text { AREA } \\ & (\mathrm{ft2} 2)\end{aligned}$

AREA LIQUID WASTE DISPOSAL SITES: (CONTINUED)

\begin{tabular}{|c|c|c|c|c|c|}
\hline$U-11 A$ & $\mathbf{R}$ & Ditch & & 51,600 & \\
\hline$U-11 B$ & NU & Ditch & & 39,200 & \\
\hline$U-12$ & R & Crib & & 3,300 & No Contamination Found \\
\hline$U-13$ & R & Crib & & 24,000 & No Contamination Found \\
\hline$U-14$ & A & Ditch & & 227,200 & \\
\hline$U-15$ & $\mathrm{R}$ & Crib & & UN & \\
\hline$z-1$ & $R$ & Crib & & 17,000 & No Contamination Found \\
\hline$z-1$ & R & Ditch & & UN & \\
\hline$z-1 A$ & $R$ & Tile Field & $\therefore$ & 75,000 & \\
\hline$Z-1 A A$ & $\mathrm{R}$. & Tile Field & & UN & \\
\hline$z-1 A B$ & $R$ & Tile Field & & UN. & \\
\hline$z-1 A C$ & R & Tile Field & & UN & \\
\hline$z-2$ & $\mathbf{R}$ & Crib & & 400 & No Contamination Found \\
\hline$z-3$ & $\mathbf{R}$ : & Crib & & 1,200 & No Contamination Found \\
\hline$z-4$ & R & Crib. & & 225 & No rontamination Found \\
\hline$z-5$ & $\mathbf{R}$ & Crib & & 5,000 & No Contamination Found \\
\hline$z-6$ & $\mathrm{R}$ & Crib & & 750 & No Contamination Found \\
\hline$z-6 A$ & $R$ & & & 750 & No Contamination Found \\
\hline$z-7$ & $\mathrm{R}$ & Crib & & 30,000 & \\
\hline$z-8$ & $R$ & French Draln & & 5,000 & No Contamination Found \\
\hline$z-9$ & $\mathrm{R}$ & Crib & & 15,000 & $\begin{array}{l}\text { Mining Demonstration; } \\
\text { No Contamination Found }\end{array}$ \\
\hline$z-10$ & $R$ & Reverse We11 & & 15,000 & \\
\hline$z-11$ & $\mathbf{R}$ & Ditch & & 26,500 & No Contamination Found \\
\hline$z-12$ & $R$ & Crib & & 28,800 & \\
\hline$z-13$ & A & French Drain & & 2 & No Contamination Found \\
\hline$z-14$ & A & French Drain & & 2 & No Contamination Found \\
\hline$z-15$ & A & French Drain & & 2 & No Contamination Found \\
\hline
\end{tabular}


RHO-CD-648, REV 1

CONTAMINATED FACILITIES LIST (CONTINUED)

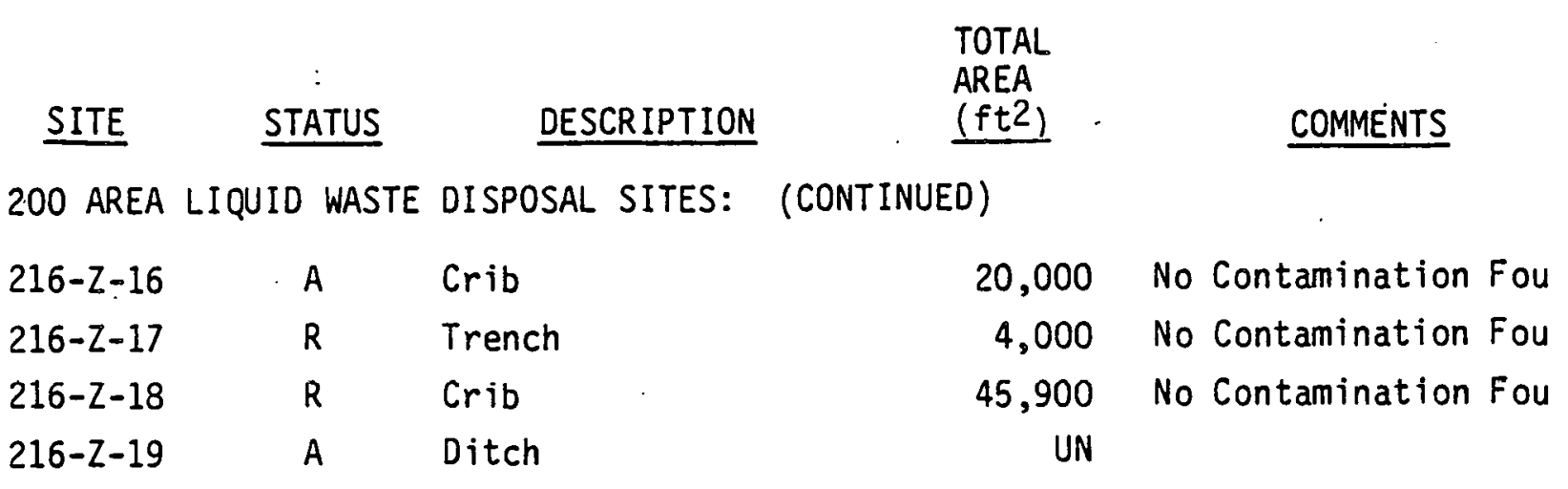

200 AREA SOLID WASTE DISPOSAL SITES:

$\begin{array}{lcll}218-E-1 & R & \text { Burial Ground } & \text { UN } \\ 218-E-2 & R & \text { Burial Ground } & \text { UN } \\ 218-E-2 A & R & \text { Burial Ground } & \text { UN } \\ 218-E-3 & \text { RELEASED } & \text { Exhumed } & \\ 218-E-4 & R & \text { Burial Ground } & \text { UN } \\ 218-E-5 & R & \text { Burial Ground } & \text { UN } \\ 218-E-5 A & R & \text { Burial Ground } & \text { UN } \\ 218-E-6 & \text { RELEASED } & \text { Exhumed } & \\ 218-E-7 & R & \text { Vault } & \text { UN No Contamination Fou } \\ 218-E-8 & R & \text { Burial Ground } & \text { UN } \\ 218-E-9 & R & \text { Equipment Storage } & \text { UN } \\ 218-E-10 & A & \text { Burial Ground } & \text { UN } \\ 218-E-12 A & R & \text { Burial Ground } & \text { UN } \\ 218-E-12 B & A & \text { Burial Ground } & \text { UN } \\ 218-E-13 & R & \text { Burial Site } & \text { UN } \\ 218-E-14 & A & \text { Burial Tunnel } & \text { UN No Contamination Fou } \\ 218-E-15 & A & \text { Burial Tunnel } & \text { UN No Contamination Fou } \\ 218-W-1 & R & \text { Burial Ground } & \text { UN } \\ 218-W-1 A & R & \text { Burial Ground } & \text { UN } \\ 218-W-2 & R & \text { Burial Ground } & \text { UN } \\ 218-W-2 A & A & \text { Burial Ground } & \text { UN } \\ 218-W-3 & R & \text { Burial Ground } & \text { UN }\end{array}$


RHO-CD-648, REV 1

CONTAMINATED FACILITIES LIST (CONTINUED)

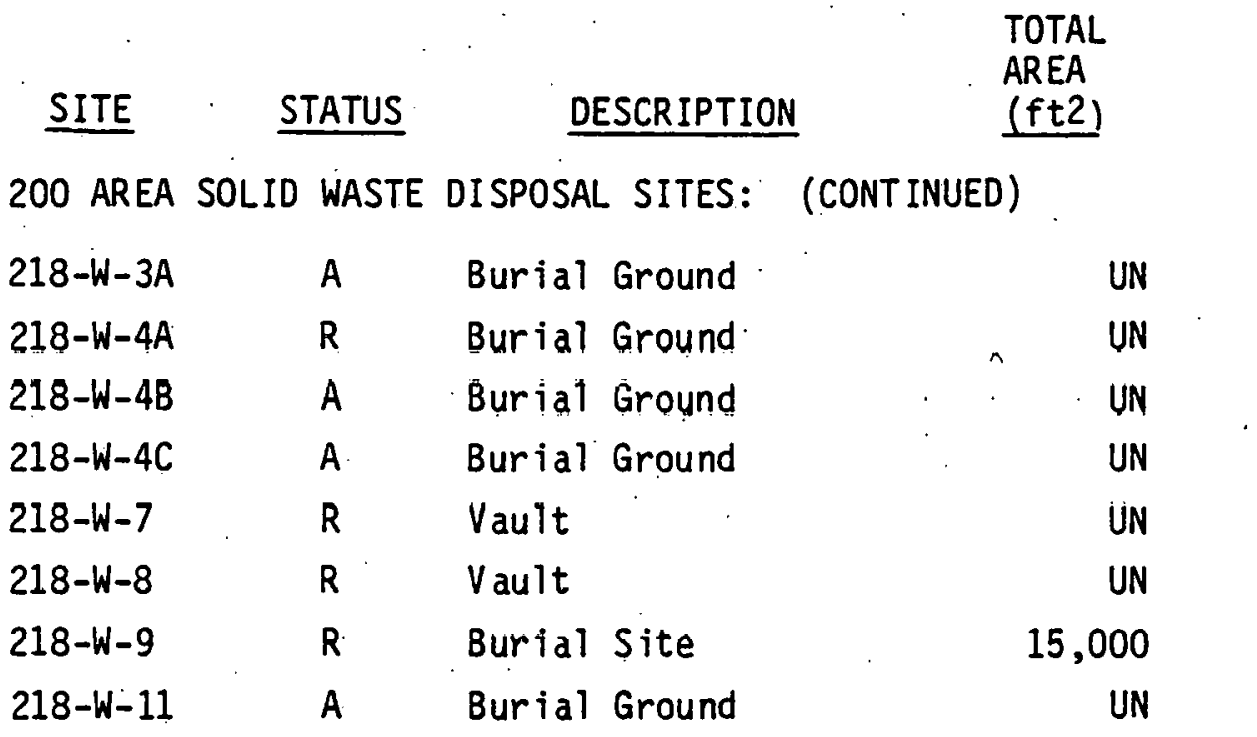

200 AREA UNPLANNED RELEASE SITES:

\begin{tabular}{|c|c|c|}
\hline$U N-216-E-1$ & $R$ & $\begin{array}{l}\text { Ground Contamination } \\
\text { Div. Box } 241-B-151\end{array}$ \\
\hline$U N-216-E-2$ & $\mathrm{R}$ & $\begin{array}{l}\text { Ground Contamination } \\
\text { DIv. Box 241-B-152 }\end{array}$ \\
\hline$U N-216-E-3$ & $\mathrm{R}$ & $\begin{array}{l}\text { Ground Contamination } \\
\text { Div. Box } 241-B-153\end{array}$ \\
\hline$U N-216-E-4$ & $\mathrm{R}$ & Line Break 241-B-153 \\
\hline$U N-216-E-5$ & $\mathrm{R}$ & $\begin{array}{l}\text { Ground Contamination } \\
\text { Div. Box 241-B-154: }\end{array}$ \\
\hline$U N-216-E-6$ & $\mathbf{R}$ & $\begin{array}{l}\text { Ground Contaminaton } \\
\text { Div. Box 241-BX-155 }\end{array}$ \\
\hline UN-216-E-7 & $\mathbf{R}$ & $\begin{array}{l}\text { Line Break 242-B to } \\
207-B\end{array}$ \\
\hline UN-216-E-8 & $\mathbf{R}$ & Line Break 221-B, R-3 \\
\hline UN-216-E-9 & $R$ & Line Break 241-CR-151 \\
\hline UN-216-E-10 & $\mathrm{R}$ & Line Break 211-C-152 \\
\hline UN-216-E-11 & $\mathrm{R}$ & $\begin{array}{l}\text { Ground Contamination } \\
B C \text { Cribs Controlled } \\
\text { Area }\end{array}$ \\
\hline
\end{tabular}


RHO-CD-648, REV 1

CONTAMINATED FACILITIES LIST (CONTINUED)

SITE STATUS DESCRIPTION

COMMENTS

200 AREA UNPLANNED RELEASE SITES: (CONTINUED)

\begin{tabular}{|c|c|c|c|c|}
\hline UN-216-E-12 & $R$ & $\begin{array}{l}\text { Catch Tank Leak } \\
241-E R-151\end{array}$ & UN & \\
\hline$U N-216-E-13$ & $R$ & Line Break 221-B, R-13 & UN & No Contamination Fou \\
\hline$U N-216-E-14$ & $R$ & $\begin{array}{l}\text { Line Break 241-C, } \\
\text { SW Corner }\end{array}$ & UN & \\
\hline$U N-216-E-15$ & $\mathbf{R}$ & $\begin{array}{l}\text { Line Leak 224-B, } \\
\text { Backside }\end{array}$ & UN & No Contamination Fou \\
\hline UN-216-W-1 & $\mathrm{R}$ & $216-S-3$ Crib & 900 & No Contamination Fou \\
\hline$U N-216-W-2$ & $\mathbf{R}$ & $\begin{array}{l}207-S \text { Retention Basin } \\
\text { Contamination }\end{array}$ & 6,750 & \\
\hline UN-216-W-3 & R & 216-S-15 Pond & 750 & \\
\hline$U N-216-W-4$ & $\mathbf{R}$ & $\begin{array}{l}\text { Ground Contamination } \\
\text { North of } 233-5\end{array}$ & UN & No Contamination Fou \\
\hline UN-216-W-5 & $\mathrm{R}$ & $\begin{array}{l}\text { Line Break 23rd \& } \\
\text { Canden }\end{array}$ & UN & $\therefore$ \\
\hline$U N-216-W-6$ & $R$ & Line Break 221-T, R-19 & UN & \\
\hline UN-216-W-7 & $\mathbf{R}$ & $\begin{array}{l}\text { Ground Contamination } \\
\text { East of } 241-T X\end{array}$ & UN & No Contamination Fou \\
\hline$U N-216-W-8$ & R & $\begin{array}{l}\text { Line Break 105TX to } \\
\text { 118TX }\end{array}$ & 12,500 & \\
\hline$U N-216-W-9$ & R & $\begin{array}{l}\text { Ground Contamination } \\
221-U, R-3-R-5\end{array}$ & 2 & 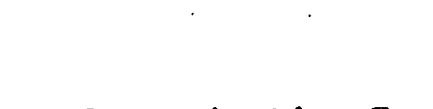 \\
\hline$U N-216-W-10$ & R & $\begin{array}{l}\text { Interface Crud from } \\
\text { Tank } 288-U\end{array}$ & UN & No Contamination Fol \\
\hline$U N-216-W-11$ & $\mathbf{R}$ & $\begin{array}{l}\text { 221-U Vessel Vent } \\
\text { Blower Pit } \\
\text { Contamination }\end{array}$ & UN & \\
\hline UN-216-W-12 & $\mathbf{R}$ : & $\begin{array}{l}\text { Line Leak Backside } \\
224-T\end{array}$ & UN & \\
\hline UN-216 -W-13 & R & $\begin{array}{l}\text { Line Break } 216-2-18 \\
\text { Crib Line }\end{array}$ & UN & - \\
\hline UN-216-W-14 & $R$ & $\begin{array}{l}\text { Leach Trench } \\
\text { NE 216-U }=10 \text { Pond }\end{array}$ & UN & \\
\hline
\end{tabular}


RHO-CD-648, REV 1

CONTAMINATED FACILITIES LIST. (CONT INUED)

\begin{tabular}{|c|c|c|c|c|}
\hline TE & STATUS & DESCRIPTION & $\begin{array}{l}\text { TOTAL } \\
\text { AREA } \\
\text { (ft2) } \\
\end{array}$ & COMMENTS \\
\hline \multicolumn{5}{|c|}{ AREA UNPLANNED RELEASE SITES: (CONTINUED) } \\
\hline$: 16-W-15$ & R & $\begin{array}{l}\text { Leach Trench } \\
\text { E 216-U-10 Pond North }\end{array}$ & UN & \\
\hline$! 16-W-16$ & $\mathrm{R}$ & $\begin{array}{l}\text { Leach Trench } \\
\text { E } 216-U-10 \text { Pond South }\end{array}$ & IIN & \\
\hline$: 16-W-17$ & $R$ & $\begin{array}{l}\text { Overflow Plain South- } \\
\text { side } 216-U-10 \text { Pond }\end{array}$ & UN & \\
\hline$! 16-W-18$ & $\mathbf{R}$ & $\begin{array}{l}\text { Line Break South End } \\
216-5-9 \text { Crib }\end{array}$ & UN & \\
\hline$: 16-W-19$ & R & $\begin{array}{l}\text { Line: Break East Side } \\
218-W-9\end{array}$ & UN & \\
\hline$: 16-W-20$ & $R$ & $\begin{array}{l}\text { Pu Spoil Trench Near } \\
\text { 216-Z-1 Ditch }\end{array}$ & UN & \\
\hline$? 16-W-21$ & R & $\begin{array}{l}\text { Sludge Pits South } \\
\text { Side } 207-U\end{array}$ & $\because$ UN & \\
\hline$! 16-W-22$ & $\mathrm{R}$ & $\begin{array}{l}\text { Sludge Pits North } \\
\text { Side } 207-U\end{array}$ & UN. & \\
\hline$? 16-W-23$ & $\mathrm{R}$ & $\begin{array}{l}\text { Fround Contamination } \\
\text { Hiliside West of } \\
241-T X=155\end{array}$ & UN & \\
\hline ?18-E-1 & $R$ & $\begin{array}{l}\text { Contaminated Concrete } \\
\text { from Underground } \\
\text { P ipe Encasement }\end{array}$ & UN & \\
\hline$? 18-E-2$ & $R$ & BC Cribs Outer Area. & UN & $\begin{array}{l}\text { Approximately } 4 \text { Square } \\
\text { Miles }\end{array}$ \\
\hline$? 18-E-13$ & $R$ & $\begin{array}{l}\text { Contaminated Concrete } \\
\text { from Underground. } \\
\text { Pipe Encasement }\end{array}$ & UN & Same as UN-218-E-1 \\
\hline$? 18-W-1$ & $\mathbf{R}$ & $\begin{array}{l}\text { Buried Canyon Cell } \\
\text { Blocks }\end{array}$ & UN & $\begin{array}{l}10 \text { Ce } 11 \text { Cover Blocks } \\
\text { from 221-T Canyon }\end{array}$ \\
\hline \multirow{2}{*}{\multicolumn{5}{|c|}{ TE MANAGEMENT FACILITIES: }} \\
\hline & & & & \\
\hline-5 & $\dot{R}$ & Hexone Tank & UN & \\
\hline$-S$ & $R$ & Hexone Tank & UN & \\
\hline
\end{tabular}


RHO-CD-648, REV. 1

CONTAMINATED FACILITIES LIST (CONTINUED)

$\underline{\text { SITE STATUS } \quad \text { DESCRIPTION }}$ (ft2)

COMMENTS

WASTE MANAGEMENT FACILITIES: (CONTINUED)

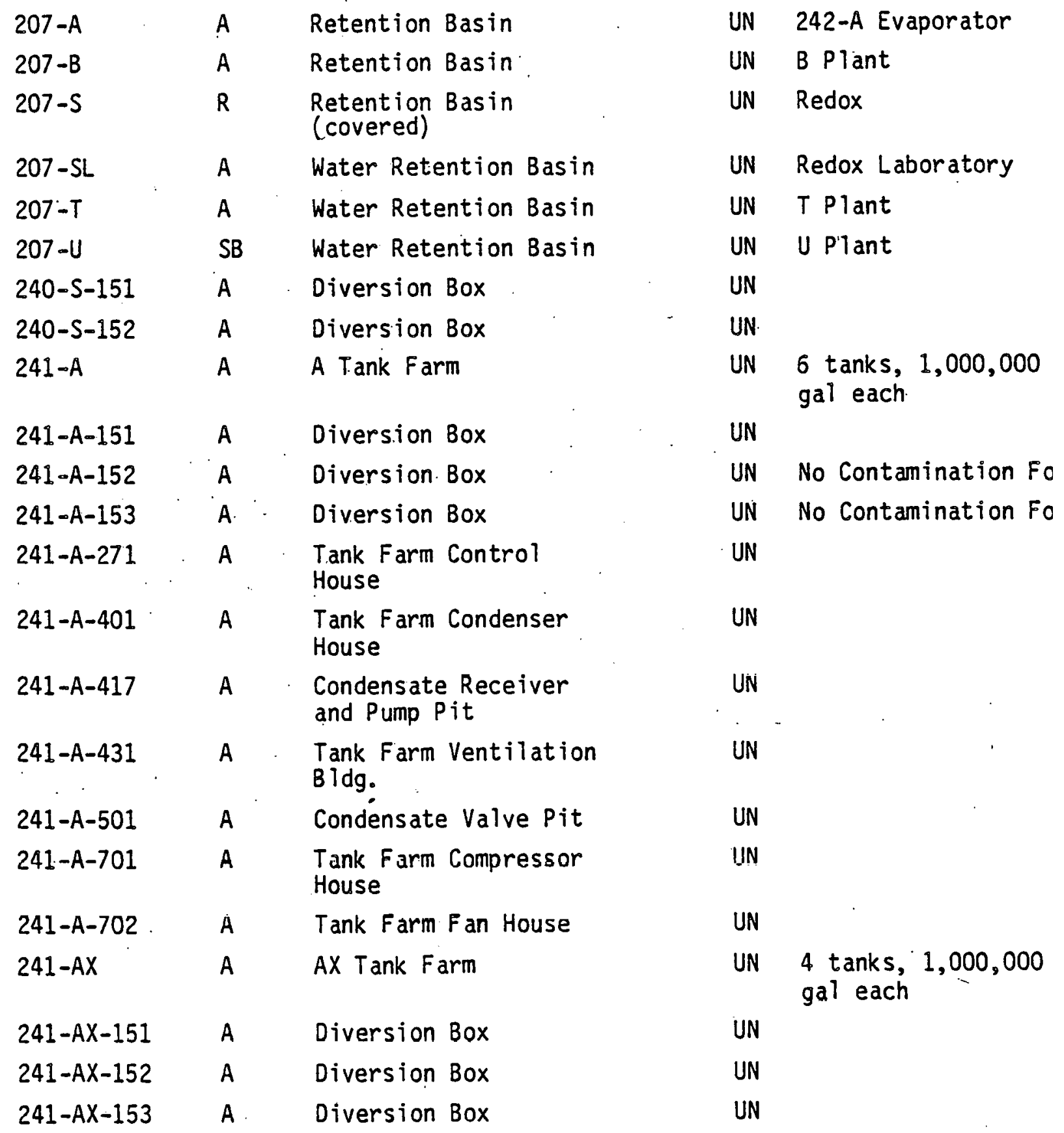


CONTAMINATED FACILITIES LIST (CONTINUED)

\begin{tabular}{|c|c|c|c|c|c|}
\hline$\underline{T E}$ & STATUS & DESCRIPTION & $\begin{array}{l}\text { TOTAL } \\
\text { AREA } \\
\text { (ft2 }\end{array}$ & & COMMENTS \\
\hline \multicolumn{6}{|c|}{ E MANAGEMENT FACILITIES: (CONTINUED) } \\
\hline$A X-501$ & A & Condensate Valve. Pit & & UN & \\
\hline$A X-801 A$ & A & $\begin{array}{l}\text { Tank Farm Control } \\
\text { House, North }\end{array}$ & & UN & \\
\hline$A X-801 B$ & A & $\begin{array}{l}\text { Tank Farm Control } \\
\text { House, South }\end{array}$ & & UN & \\
\hline$A X-801 C$ & A & $\begin{array}{l}\text { Tank Farm Diversion } \\
\text { House }\end{array}$ & & UN & South of A Farm \\
\hline AY & A & AY Tank Farm & & UN & $\begin{array}{l}2 \text { tanks, } 1,000,000 \\
\text { gal each }\end{array}$ \\
\hline$A Y-151$ & A & Pump Out Pit & & UN & No Contamination Found \\
\hline$A Y-152$ & A & Pump Out Pit & & UN. & No Contamination Found \\
\hline AY -501 & A & Condensate Valve Pit & & UN & \\
\hline AY-801 & A & $\begin{array}{l}\text { Tank Farm Instrument } \\
\text { House }\end{array}$ & & UN & \\
\hline$A Z$ & A & AZ Tank Farm & & UN & $\begin{array}{l}2 \text { tanks, } 1,000,000 \\
\text { gal each }\end{array}$ \\
\hline$A Z-151$ & $A$ & Diverter station. & & UN & No Contamination Found \\
\hline$A Z-152$ & A & Sluice Transfer Box & & UN & \\
\hline$A Z-501$ & A & Condensate Valve Pit & & UN & \\
\hline$A Z-801$ & $A$ & $\begin{array}{l}\text { Tank Farm Instrument } \\
\text { House }\end{array}$ & & UN & \\
\hline 3 & A & B Tank Farm & - & UN & $\left\{\begin{array}{l}\text { 4. tanks, } 55,000 \text { gal } \\
\text { each; } 12 \text { tanks, } \\
533,000 \text { gal each }\end{array}\right.$ \\
\hline$B-151$ & A & Dtverstion Box & & UN & \\
\hline$B-152$ & A & Diversion Box & & UN & No Contamination Found \\
\hline$B-153$ & A & Diversion Box & & UN & No Contamination Found \\
\hline$B-154$ & $A$ & Diversion Box & & UN & - \\
\hline$B-251$ & A & Diversion Box & & UN & \\
\hline$B-252$ & A & Diversion Box & & UN & No Contamination Found \\
\hline
\end{tabular}


RHO-CD-648, REV 1

CONTAMINATED FACILITIES LIST .(CONTINUED)

\begin{tabular}{|c|c|c|c|c|}
\hline SITE & STATUS & DESCRIPTION & $\begin{array}{l}\text { TOTAL } \\
\text { AREA } \\
(\mathrm{ft2})\end{array}$ & COMMENTS \\
\hline \multicolumn{5}{|c|}{ WASTE MANAGEMENT FACILITIES: (CONTINUED) } \\
\hline $241-B-701$ & A & $\begin{array}{l}\text { Instrument Air. Com- } \\
\text { pressor Building }\end{array}$ & UN & \\
\hline $241-B R$ & A & $\begin{array}{l}\text { B Farm Waste Metal } \\
\text { Recovery Facilities }\end{array}$ & UN & \\
\hline $241-B R-152$ & A & Diversion Box & UN & \\
\hline $241-B X$ & A & BX Tank Farm & UN & $\begin{array}{l}12 \text { tanks, } 533,000 \\
\text { gat each. }\end{array}$ \\
\hline $241-B X-153$ & A & Diversion Box & UN & \\
\hline $241-B X-154$ & A & Diversion Box & UN & \\
\hline $241-B X-155$ & A & Diversion Box : & UN & \\
\hline $241-B \times R$ & A & $\begin{array}{l}\text { BX Farm Waste Metal } \\
\text { Recovery Facilities }\end{array}$ & UN. & \\
\hline $241-B \times R-151$ & A & Diversion Box & UN & \\
\hline $241-B \times R-152$ & A & Diversion Box & UN & \\
\hline 241-BSR-153 & A & Diversion Box & UN & \\
\hline $241-B Y$ & A & BY. Tank Farm & UN & $\begin{array}{l}12 \text { tanks, } 750,000 \\
\text { gal each }\end{array}$ \\
\hline $241-B Y-254$ & $A$ & $\begin{array}{l}\text { Control House and } \\
\text { Compressor }(\text { ITS-2) }\end{array}$ & UN & \\
\hline $241-B Y-301$ & $A$ & $\begin{array}{l}\text { Control House In-Tank } \\
\text { Solidification (ITS-1) }\end{array}$ & UN & $\cdot$ \\
\hline $241-B Y-302$ & $A$ & $\begin{array}{l}\text { Compressor House } \\
\text { (ITS-1) }\end{array}$ & UN & \\
\hline $241-B Y R$ & A & $\begin{array}{l}\text { BY Farm Waste Metal } \\
\text { Recovery Facilities }\end{array}$ & UN & \\
\hline 241-BYR-152 & A & Diversion Box & UN & \\
\hline $241-8 Y R-153$ & A & Diversion Box & UN & \\
\hline $241-B Y R-154$ & $A$ & Diversion Box & UN & 2 \\
\hline $241-C$ & $A$ & C Tank Farm & UN & $\left\{\begin{array}{l}4 \text { tanks, } 55,000 \text { gal } \\
\text { each; } 12 \text { tanks, } \\
500,000 \text { gal each }\end{array}\right.$ \\
\hline $241-C-151$ & A & Diversion Box & UN & \\
\hline
\end{tabular}


CONTAMINATED FACILITIES LIST (CONTINUED)

\begin{tabular}{|c|c|c|c|c|c|}
\hline [TE & STATUS & DESCR IPTION & \multicolumn{2}{|c|}{$\begin{array}{l}\text { TOTAL } \\
\text { AREA } \\
(f+2)\end{array}$} & COMMENTS \\
\hline ГE MANAG & ENT FAC & ITIES: (CONTINUED) & & & \\
\hline$-C-152$ & $A$ & Diversion Box & & UN & \\
\hline$-C-153$ & $A$ & Diversion Box & & UN & \\
\hline$-C=252$ & $A$ & Diverşion Box & & UN & No Contamination Found \\
\hline$-C-801$ & $\mathbf{R}$ & Cesium Loadout BIdg. & & UN & \\
\hline$-C R$ & A & $\begin{array}{l}\text { C Farm Waste Metal } \\
\text { Recovery Facilities. }\end{array}$ & & UN & \\
\hline$-C R-151$ & A. & Diversion Box & & UN & \\
\hline$-C R-152$ & $A$ & Diversion Box & & UN & \\
\hline$-C R-153$ & $A$ & Diversion Box & & UN & No Contamination Found \\
\hline$-C R-271$ & $A$. & $\begin{array}{l}\text { Waste Disposal Control } \\
\text { House. }\end{array}$ & & UN & \\
\hline$-c x$ & $R$ & CX Tank Farm & & UN & $\begin{array}{l}3 \text { tanks, } 3,000 \mathrm{gal} \\
\text { each }\end{array}$ \\
\hline -ER-151 & $A$ & Diversion Box & & UN & \\
\hline$-E R-152$ & $A$ & Diversion Box & & UN & \\
\hline$-E R-153$ & $A$ & Diversion Box & & UN & \\
\hline$-E W-151$ & A & Vent Station & & UN & \\
\hline$-S$ & $A$ & S Tank Farm & & UN & $\begin{array}{l}12 \text { tanks, } 750,000 \\
\text { gal each }\end{array}$ \\
\hline$-\$-151$ & $A$ & Diversion Box & & UN. & \\
\hline$-S-152$ & $A$ & Diversion Box & & UN & \\
\hline$-S-153$ & $A$ & Diversion Box & & UN & \\
\hline$-S-271 A$ & $A$ & $\begin{array}{l}\text { Electrical and Instru- } \\
\text { ment Control House }\end{array}$ & & UN & \\
\hline$-5-271 B$ & $A$ & $\begin{array}{l}\text { Electrical and Instru- } \\
\text { ment Control House } \\
\text { Switches }\end{array}$ & & UN & . \\
\hline$-S X$ & $A$ & SX Tank Farm & & UN & $\begin{array}{l}15 \text { tanks, } 1,000,000 \\
\text { gal each }\end{array}$ \\
\hline$-5 x-151$ & $A$ & Diversion Box & & UN & \\
\hline$-S X-152$ & $A$ & Diversion Box & & UN & \\
\hline
\end{tabular}




\section{$\frac{\text { SITE }}{\text { STATUS }} \frac{\text { DESCRIPTION }}{\text { (CONTINUED) }}$}

\begin{tabular}{|c|c|c|c|c|}
\hline $241-5 X-271$ & A & $\begin{array}{l}\text { Tank Farm Control } \\
\text { House }\end{array}$ & UN & \\
\hline $241-5 X-401$ & A & Condenser House, North & UN & \\
\hline $241-5 x-402$ & A & Condenser House, South & UN & \\
\hline $241-5 X-701$ & A & Compressor House & UN & \\
\hline $241-S Y$ & A & SY Tank Farm & UN & $\begin{array}{l}3 \text { tanks, } 1,000,000 \\
\text { gal each }\end{array}$ \\
\hline $241-S Y-271$ & A & $\begin{array}{l}\text { Instrument and Elec- } \\
\text { trical Control House }\end{array}$ & UN & \\
\hline $241-\mathrm{T}$ & A & $T$ Tank Farm & UN & $\left\{\begin{array}{l}4 \text { tanks, } 55,000 \\
\text { gal each; } 12 \text { tanks, } \\
533,000 \text { gal each }\end{array}\right.$ \\
\hline $241-T-1.51$ & A & Diversion Box & UN & No Contamination Found \\
\hline $241-T-152$ & $A$ & Diversion Box & UN & \\
\hline $241-T-153$ & A & Diversion Box & UN & \\
\hline $241-T-252$ & A & Diversion Box & UN & No Contamination Found \\
\hline $241-T-701$ & A & $\begin{array}{l}\text { Instrument Air } \\
\text { Compressor House }\end{array}$ & UN & \\
\hline $241-T R$ & A & $\begin{array}{l}\text { I Farm Waste Metal } \\
\text { Recovery Facilities }\end{array}$ & UN & \\
\hline $241-T R-152$ & A & Diversion Box & UN & \\
\hline $241-T R-153$ & A & Diversion Box & UN & No Contamination Found \\
\hline $241-T X$ & A & TX Tank Farm & UN & $\begin{array}{l}18 \text { tanks, } 750,000 \\
\text { gal each }\end{array}$ \\
\hline $241-T X-153$ & A & Diversion Box & UN & \\
\hline $241-T X-154$ & A & Diversion Box & UN & \\
\hline $241-T X-155$ & A & Diversion Box & UN & \\
\hline 241-TXR & A & $\begin{array}{l}\text { TX Farm Waste Metal } \\
\text { Recovery Facilities }\end{array}$ & UN & 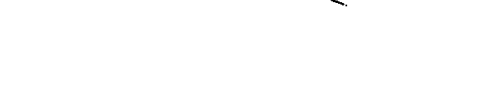 \\
\hline 241-TXR-151 & A & Diversion Box & UN & \\
\hline $241-T X R-152$ & A & Diversion Box & UN & \\
\hline
\end{tabular}


CONTAMINATED FACILITIES LIST (CONTINUED)

EE STATUS $\therefore$ UESCRIPTION $\begin{aligned} & \begin{array}{l}\text { TOTAL } \\ \text { AREA } \\ (f t 2)\end{array} \\ & \text { COMMENTS }\end{aligned}$

: MANAGEMENT FACILITIES: (CONTINUED)

\begin{tabular}{|c|c|c|c|c|}
\hline$X X R-153$ & A & Diversion Box & UN & \\
\hline$X X R-244$ & A & Vault & UN & \\
\hline$\Gamma Y$ & $A$ & TY Tank Farm & UN & $\begin{array}{l}6 \text { tanks, } 750,000 \\
\text { gal each }\end{array}$ \\
\hline TY -153 & A & Diversion Box & UN & \\
\hline 1 & A & U Tank Farm & UN & $\left\{\begin{array}{l}4 \text { tanks, } 55,000 \text { gal } \\
\text { each; } 12 \text { tanks, } \\
533,000 \text { gal each }\end{array}\right.$ \\
\hline J-151 & A & Diversion Box & UN & \\
\hline$J-152$ & A & Diversion Box & UN & \\
\hline$J-153$ & A & Diversion Box & UN & \\
\hline$J-252$ & A & Diversion Box & UN & No Contamination Found \\
\hline$J-271$ & $A$ & U Farm Control House & UN & \\
\hline $1-361$ & A & Catch Tank & UN & \\
\hline $1=702$ & A & Vault Ventilation Bldg. & UN & \\
\hline $\mathbb{R}$ & A & $\begin{array}{l}\text { U Farm Waste Metal } \\
\text { Recovery Facilities }\end{array}$ & UN & \\
\hline$J R-151$ & A & Diversion Box & UN & No Contamination Found \\
\hline$J R-152$ & A & Diversion Box & UN & No Contamination Found \\
\hline$J R-153$ & A & Diversion Box & UN & No Contamination Found \\
\hline$J R-154$ & $A$ & Diversion Box & UN & No Contamination Found \\
\hline$J X-154$ & A & Diversion Box & UN & \\
\hline$\checkmark-151$ & $A$ & Catch Tank & UN & $\begin{array}{l}\text { For Vent Station } \\
241-E W-151\end{array}$ \\
\hline $\mathbb{R}$ & A & Vault & UN & \\
\hline$?$ & A & $\begin{array}{l}\text { Tank Farm Waste Dis- } \\
\text { posal Sump Area }\end{array}$ & UN & \\
\hline$? A$ & A & Sample Building & UN & Belong to 234-5; are \\
\hline IB & $A$ & $\begin{array}{l}\text { Open Area Slab-Struc- } \\
\text { ture Uranium Storage }\end{array}$ & UN & not in tank farms \\
\hline ?C & A & Sump Vent Enclosure & UN & \\
\hline
\end{tabular}


RHO-CD-648, REV 1

CONTAMINATED FACILITIES LIST (CONTINUED)

\begin{tabular}{|c|c|c|c|c|}
\hline SITE & STATUS & DESCRIPTION & $\begin{array}{l}\text { TOTAL } \\
\text { AREA } \\
\left(\mathrm{ft}^{2}\right) \\
\end{array}$ & COMMENTS \\
\hline \multicolumn{5}{|c|}{ WASTE MANAGEMENT FACILITIES: (CONTINUED) } \\
\hline $242-A$ & A . & Evaporator & UN & : \\
\hline $242-A-702$ & A & Turbine Building & UN & \\
\hline $242-B-151$ & A & Diversion Box & UN & \\
\hline $242-5$ & A & Evaporator Facility & UN & \\
\hline $242-5-702$ & A & $\begin{array}{l}\text { Turbine Bldg, } \\
\text { Ventilation }\end{array}$ & UN & \\
\hline $242-T$ & A & $\begin{array}{l}\text { Waste Disposal Evapo- } \\
\text { rator Building }\end{array}$ & UN & \\
\hline $242-T-151$ & A & Diversion Box & UN & \\
\hline 242-TA & A & Vault & UN. & \\
\hline 242-TB & A & Vent House & UN & \\
\hline 244-A & A & $\begin{array}{l}\text { Waste Vault and } \\
\text { Instrument House }\end{array}$ & UN) & \\
\hline 244-AR & A & $\begin{array}{l}\text { Sludge Vault Storage } \\
\text { and Processing }\end{array}$ & UN & $\begin{array}{l}\text { Not located in a } \\
\text { tank farm }\end{array}$ \\
\hline 244-AR-712 & A & $\begin{array}{l}\text { Vault Air Lock and } \\
\text { Loadout Building }\end{array}$ & UN & \\
\hline 244-BXR & A & $\begin{array}{l}\text { Waste Disposal Vault, } \\
\text { Underground }\end{array}$ & UN & \\
\hline $244-C R$ & A & $\begin{array}{l}\text { Waste Disposal Vault, } \\
\text { Underground }\end{array}$ & UN & \\
\hline 244-TXR & A & Waste Disposal Vault & UN & \\
\hline $252-B Y$ & $A$ & Subștation, $13.8 \mathrm{kV}$ & UN & $\begin{array}{l}\text { Previously ITS-2 } \\
\text { Substation }\end{array}$ \\
\hline 271-UR & A & $\begin{array}{l}\text { Underground Services } \\
\text { for U Farm Control } \\
\text { House }\end{array}$ & UN & $\begin{array}{l}\text { Part of Building } 271 \\
\text { Slab }\end{array}$ \\
\hline
\end{tabular}

